\title{
Androgen receptor roles in hepatocellular carcinoma, fatty liver, cirrhosis and hepatitis
}

\author{
Wen-Lung Ma,2, Hsueh-Chou Lai ${ }^{1}$, Shuyuan $\mathrm{Yeh}^{2}$, Xiujun $\mathrm{Cai}^{3}$ and \\ Chawnshang Chang ${ }^{1,2}$
}

${ }^{1}$ Sex Hormone Research Center, Department of Gastroenterology, Graduate Institute of Clinical Medical Science, China Medical University/Hospital, Taichung 404, Taiwan, Republic of China

${ }^{2}$ George Whipple Lab for Cancer Research, Departments of Pathology and Urology, and The Wilmot Cancer Center, University of Rochester Medical Center, Rochester, New York 14642, USA

${ }^{3}$ Chawnshang Chang Liver Cancer Center, Department of General Surgery, Sir Run-Run Shaw Hospital,

Zhejiang University, Hangzhou, China

\author{
Correspondence \\ should be addressed \\ to C Chang or X Cai \\ Emails \\ chang@urmc.rochester.edu or \\ cxjzu@hotmail.com
}

\begin{abstract}
Androgen/androgen receptor (AR) signaling plays important roles in normal liver function and in progression of liver diseases. In studies of noncancerous liver diseases, AR knockout mouse models of liver disease have revealed that androgen/AR signaling suppresses the development of steatosis, virus-related hepatitis, and cirrhosis. In addition, studies have shown that targeting AR in bone marrow-derived mesenchymal stem cells (BM-MSCs) improves their self-renewal and migration potentials, thereby increasing the efficacy of BM-MSC transplantation as a way to control the progression of cirrhosis. Androgen/AR signaling is known to be involved in the initiation of carcinogen- or hepatitis $B$ virus-related hepatocellular carcinoma (HCC). However, studies have demonstrated that AR, rather than androgen, plays the dominant role in cancer initiation. Therefore, targeting AR might be an appropriate therapy for patients with early-stage HCC. In contrast, androgen/AR signaling has been shown to suppress metastasis of HCC in patients with late-stage disease. In addition, there is evidence that therapy comprising Sorafenib and agents that enhance the functional expression of AR may suppress the progression of late-stage HCC.
\end{abstract}

\section{Key Words \\ - androgen receptor (AR) \\ - hepatocellular carcinoma (HCC)}

\section{Introduction}

\section{Liver function and liver diseases}

The liver is the largest visceral organ responsible for systemic homeostasis of blood glucose as well as lipid and protein metabolism. It is also responsible for most xenobiotic clearance even when parts of the liver have been damaged (Rinaldi et al. 2011). The liver has extraordinary repair capacity, which partially explains why a diseased/damaged liver is usually asymptomatic. Although the etiologies of liver diseases vary, many share common post-damage healing process pathways. Liver damage can result in the accumulation of matrix proteins, the formation of scars, and the alteration of tissue structure and function. As fibrosis develops, chronic compensatory scar-healing processes in the liver begin to take place. Once irreversible distortion of the hepatic architecture and vascular structure occurs, the cirrhotic liver begins to replace the functional hepatic units (Schiff et al. 2003). Progression of cirrhosis can lead to liver failure or malignant transformation of hepatocytes. 
Although cirrhosis is one of the etiological factors contributing to the hepatocarcinogenesis process, a significant number of patients without cirrhosis develop hepatocellular carcinoma (HCC), indicating that the disease process involves oncogenic events and virusrelated factors.

Hepatitis B virus (HBV) is a well-known etiological factor contributing to cirrhotic liver progression and early HCC development. Antiviral agents, such as lamivudine and adefovir have been found to improve cirrhotic liver function in some studies (Aspinall et al. 2011), but have not been shown to have anti-carcinogenic effects in other studies (Kwon \& Lok 2011, Peng et al. 2012). In addition, there is evidence that these anti-viral agents have little effect on survival of patients with advanced-stage disease (Shin et al. 2012) or on disease recurrence after hepatectomy for HCC (Chan et al. 2011).

\section{Gender differences in liver diseases and their linkage to androgen/androgen receptor}

There are four major liver diseases associated with gender (Guy \& Yee 2009): steatosis (Wild et al. 2004, Yang et al. 2009), hepatitis (Baig 2009, Yang et al. 2010), cirrhosis (Maheshwari \& Thuluvath 2011, Huang et al. 2013), and liver cancer (Yeh \& Chen 2010). A study conducted in the United States by Weston et al. (2005) showed that the prevalence of fatty liver and cirrhosis, nonalcoholic fatty liver disease (NAFLD), was 3.5 times higher in men than in women. In addition, Baig (2009) showed that the prevalence of HCC was higher among men than among women (range, $2.5: 1-7: 1$ ). Several factors may contribute to the gender difference in liver diseases, including age, alcohol consumption, diabetes, hepatic toxins, virus infection, and variation in sex hormones (Yeh \& Chen 2010). This review focuses on androgens and their receptors (androgen receptor, AR), as they may represent the major factors that contribute to the gender difference in various liver diseases.

Androgens are synthesized mainly in the testes, although some androgens form in the adrenal glands (Oshima 1968). Androgens act through the AR, a transcription factor that belongs to the nuclear receptor superfamily. AR exerts physiological and pathological functions in organisms by translocating to the nucleus upon binding to androgens (Chang et al. 1988), where it binds to specific DNA sequences known as androgen response elements (AREs; Claessens et al. 2001) in conjunction with various AR co-factors (Yeh et al. 1999). The AR complex can therefore regulate the expression of genes that participate in various physiological and pathological functions (Bluemn \& Nelson 2012). In certain conditions, androgens can exert biological functions in some diseases through a non-AR signaling mechanism (Miyamoto et al. 2007). The effects of androgen and its receptor can be either transitory or long term and can have either local or systemic impacts on organ function. The most well-known androgen/ AR-dependent cancer is prostate cancer. Ablation of androgen/AR actions is currently the gold standard for treating patients with prostate cancer; however, not all patients respond to this treatment (Seruga \& Tannock 2011). Although androgen/AR plays a role in liver development in the embryonic stage, the maximum dimorphism of androgen/AR effects seems to occur after puberty (Waxman \& O'Connor 2006) via the influence of the activity of the hypothalamus-pituitary-gonad axis. The differential secretion of growth hormone (GH) between men and women may have different impacts on liver function in the adult stage of life. Studies have shown that in men, GH is released in high-amplitude; however, in women there are low frequency bursts while GH is released in low-amplitude but with high-frequency pulses (Lund et al. 1991, Mode et al. 1992).

In this review, we focus on the roles androgen/AR play in the processes of liver disease. In the first part of the review, we discuss androgen/AR signaling in noncancerous liver diseases but include a discussion on the precursors to liver cancer development. In the second part of the review, we discuss the involvement of androgen/AR signaling in liver cancer and potential therapeutic strategies that specifically target AR.

\section{Part I: androgen/AR signaling in noncancerous liver diseases}

\section{Roles of androgen/AR signaling in the development of steatosis}

Steatosis is the abnormal retention of lipids within hepatic cells. Excess lipid accumulation in vesicles displaces the cytoplasm. When the vesicles are large enough to distort the nucleus, the condition is known as macro-vesicular steatosis, otherwise the condition is known as microvesicular steatosis (Hashizume et al. 2007). The most common risk factors associated with steatosis are diabetes mellitus, hypertension, obesity, and alcoholism (Sparks \& Sparks 2008). Malnutrition can also cause the overmobilization of fat from adipocytes to liver where lipid metabolism occurs (Williams 2006). The breakdown of

Published by Bioscientifica Ltd. 
large amounts of ethanol in alcoholic drinks produces large amounts of chemical energy in the form of NADH (reduced form of nicotinamide adenine dinucleotide), which signals cells to inhibit the breakdown of fatty acids and, simultaneously, to increase the synthesis of fatty acids. This 'false sense of energy' may then result in more lipids being created than are needed. Failure of lipid metabolism can also lead to impaired lipid breakdown, resulting in the accumulation of unused lipids in the hepatocytes. Finally, certain toxins, such as carbon tetrachloride, aspirin, and diphtheria toxin, can interfere with the cellular machinery involved in lipid metabolism.

Androgen/AR signaling suppresses the development of steatosis Many studies have shown that androgen/AR signaling suppresses the development of steatosis. For example, Jacqueson et al. (1978) reported that androgen (19-nortestosterone-phenylpropionate) had a protective effect on Amanita phalloides-induced hepatic steatosis and Saint-Aubert et al. (1980) found that a dose of testosterone injection for 1 month before subtotal hepatectomy could suppress liver steatosis in rats.

However, there are inconsistencies in the findings from studies on the roles androgens and their receptors play in the development of NAFLD. Although several human clinical studies (Vassilatou et al. 2010, Schwingel et al. 2011a,b, Jones et al. 2012) and an animal study (Chow et al. 2011) have shown that androgens might promote NAFLD, other studies have shown that androgens protect against the development of the disease (Haider et al. 2010, Magyar et al. 2011, Zhang et al. 2013). There is little explanation of such inconsistencies, even the patients with NAFLD in these studies were quite different, with polycystic ovarian syndrome (PCOS) female patients (Jones et al. 2012) or people using synthetic anabolic androgens (Schwingel et al. 2011a, 2011b) in studies showing positive roles played by androgens to promote NAFLD vs hypogonadal elderly men (Haider et al. 2010) in other studies showing the negative roles played by androgens to suppress NAFLD.

In animal models used to study fatty liver, androgens were demonstrated to play a positive role in an aromatase knockout mouse model (Chow et al. 2011); however, androgens were also proven to be suppressors of the disease in rats fed a high-fat diet (HFD; Zhang et al. 2013). Furthermore, C57BL/6 mice receiving the anti-androgen hydroxyflutamide were shown to have a higher incidence of NAFLD (Takahashi et al. 2012).

In contrast, the effects of $\mathrm{AR}$ on steatosis are less controversial. In an HFD-induced NAFLD mouse model, the loss of AR in the whole body (GARKO) was shown to lead to higher insulin insensitivity and the development of diabetes (Lin et al. 2005). Similar results were confirmed in mice that only lacked hepatic AR (L-ARKO), indicating that hepatic AR might play negative roles in HFD-induced NAFLD (Lin et al. 2008). Furthermore, aged male mice lacking hepatic AR developed hepatic micro-vesicle steatosis, whereas WT aged mice did not (Lin et al. 2008). These two in vivo mouse models show that hepatic AR might play a role in the suppression of NAFLD.

Lund et al. (1991) found that AR might directly regulate carnitine palmitotyltransferase 1 and that AR might exert its function by phosphorylating 3-hydroxy-3methyl-glutaryl-CoA reductase. Furthermore, Lin et al. (2008) showed that AR might suppress fatty acid de novo synthesis by decreasing the expression of sterol regulatory element-binding protein 1c (SREBP1). They also found that AR might induce insulin sensitivity by modulating phosphoinositide-3 kinase activity and by suppressing the expression of phosphenolpyruvate carboxykinase and protein-tyrosine phosphatase 1B (Lin et al. 2008).

\section{Potential AR-targeted therapies for steatosis} NAFLD can progress to nonalcoholic steatohepatitis (NASH), fibrosis, cirrhosis, and HCC (Dima et al. 2012). Most treatments for NAFLD focus on lifestyle modifications without intervention (Dima et al. 2012). Ongoing clinical trials suggest that statins, fibrates, and other lipid-lowering medicines may lead to improvements in liver biochemistry and histology in patients with NAFLD/NASH, although the potential side effects remain unclear (Dima et al. 2012). Metformin, the generally recommended first-line treatment for type 2 diabetes, was also found to be effective in the treatment of NAFLD (Cicero et al. 2012). However, Weickert et al. (2012) reported that metformin might lead to suppression of serum androgen levels in patients with PCOS. It remains unclear whether this suppressive effect of metformin on androgen observed in patients with PCOS would also occur in men with NAFLD. Importantly, it may be worth testing to see whether therapies that enhance AR signaling, either by increasing AR expression or the expression of its downstream genes, can halt the progression of NAFLD.

\section{Androgen/AR signaling in cirrhotic liver with liver regeneration}

Cirrhosis is the 12th leading cause of death in the United States (Heron et al. 2009) and is associated with a 10-year mortality rate ranging from 32 to $66 \%$ (Sorensen et al. 2003),

Published by Bioscientifica Ltd. 
depending on whether the cirrhosis is alcohol-related cirrhosis (ARC), virus-induced hepatic cirrhosis, or nonalcoholic cirrhosis. Since patients with liver cirrhosis are at risk for developing HCC (Aspinall et al. 2011), early treatment of liver cirrhosis with proper therapy will not only improve cirrhotic symptoms but also prevent HCC incidence.

Androgen/AR signaling is associated with the progression of steatosis to cirrhosis Cirrhosis generally arises from chronic liver injury. During the injury-healing process, the damaged liver can develop fibrotic lesions that may lead to loss of normal hepatic function, impaired liver regeneration, aberrant polarity for cell proliferation, and obstruction of the portal system.

NAFLD/NASH is the most common cause of chronic liver disease in western countries (Weston et al. 2005), and NAFLD/NASH can lead to permanent liver damage with cirrhosis if liver cells are replaced by scar tissue (Swift et al. 2001). Scar tissue blocks the flow of blood through the liver and slows the processing of nutrients, hormones, drugs, and naturally produced toxins (Bradbury 2006).

White et al. $(2012 a, b)$ found that high serum testosterone level is associated with advanced steatosis and cirrhosis. Early studies indicated that in males the prevalence of muscular cytochrome P450 enzymes was suppressed during the progression of fatty liver to cirrhosis (Littmann et al. 1973, Murray et al. 1992). Interestingly, it was reported that feminization (e.g., gynecomastia) is an important factor linking the progression of steatosis (Green 1977).

The linkage between male hypogonadism and hypotestosteronemia in patients with ARC suggests that androgen/AR signaling might play negative roles in the development of ARC (Green 1977). In men, cirrhosis manifests as hypogonadism with reduced testicular size and clinical features of inadequate testicular function. Between 50 and $75 \%$ of cirrhotic men have both macroscopic and histological evidence of testicular atrophy, and as many as $90 \%$ of cirrhotic men show some degree of erectile dysfunction (Green 1977). Furthermore, men with cirrhotic liver have a decreased incidence of benign prostatic hypertrophy and gynecomastia is found in about $40 \%$ of cirrhotic men (Yoshitsugu \& Ihori 1997).

\section{Androgen/AR signaling suppresses the develop-} ment of cirrhosis Although transdermal administration of testosterone has been shown to improve symptoms of hypogonadism and gynecomastia (Yurci et al. 2011), most testosterone replacement therapies have little effect on cirrhosis (Nieschlag et al. 1977). Similar results were also reported by Gluud et al. (1987) and Gluud (1988), who showed that oral testosterone treatment yielded little change in liver pathogenesis in men with ARC, even though such treatment significantly reduced the prevalence of gynecomastia. Similarly, a large randomized clinical trial also found that administration of androgens had little effect on ARC (Rambaldi \& Gluud 2006).

However, Kley (1979) reported that administration of testosterone to male patients with ARC yielded some improvement in ARC symptoms. Importantly, Thole et al. (2004) reported that administration of steroidal or nonsteroidal anti-androgens, such as flutamide or cimentidin, might lead to cirrhosis, suggesting that androgen/AR signaling might protect against the progression of cirrhosis.

\section{Potential new therapies via targeting AR for} treatment of liver cirrhosis via modulation of liver regeneration Liver regenerative capacity is also associated with the development of cirrhosis (Michalopoulos \& DeFrances 1997). Both intrinsic (Cressman et al. 1994, 1996) and extrinsic (El-Ansary et al. 2012, Takami et al. 2012) mechanisms of liver regeneration have been reported. Intrinsic factors include the proliferation of hepatocytes and the self-renewal capacity of oval cells (hepatic stem/ progenitor cells) (Sherwood et al. 2005), whereas the extrinsic factors include circulating bone marrow-derived mesenchymal stem cells (BM-MSCs) and infiltrating monocytes/macrophages (Cornell et al. 1990, Seki et al. 2000). The intrinsic repair system, however, is not effective in patients with irreversible chronic liver damage. Therefore, potential approaches to treating cirrhosis should focus on the extrinsic repair system.

BM-MSCs are involved in the liver regeneration process. Chen et al. (2010) revealed that endogenous BM-MSCs could be recruited into fibrotic lesions of mice with injured livers. Moreover, Fang et al. (2004) found that donor transplantation of Flk1 (CD309)-MSCs into mice with CCl4-induced liver fibrosis leads to improvement of liver function. Furthermore, autologous transplantation of BM-MSCs into patients with cirrhotic liver resulted in a temporary halt to disease progression (Vanneaux et al. 2013).

El-Ansary et al. (2012) conducted a Phase II clinical trial using un-differentiated and differentiated MSCs in patients with $\mathrm{HCV}$-induced cirrhosis and found that both types of MSCs resulted in improvement of liver function. In a review of trials of autologous MSC infusion into cirrhotic patients, Takami et al. (2012) found that the

Published by Bioscientifica Ltd. 
therapy resulted in improvement of liver function and in prolonged survival in some patients.

Using mouse models of CCl4- and thioacetamideinduced liver cirrhosis, Huang et al. (2013) revealed that androgen/AR exhibited suppressive effects on the renewal capacity of BM-MSCs and adipose-derived MSCs by modulating the EGFR-mediated Erk and Akt pathways. Targeting AR in BM-MSCs via either AR-siRNA or ASC-J9 (an AR degradation enhancer) (Miyamoto et al. 2007, Yang et al. 2007) enhanced the self-renewal capacity and migration of BM-MSCs and resulted in reduced inflammation and fibrotic stress. AR-siRNA and ASC-J9 might, therefore, enhance the efficacy of autologous BM-MSC transplantation as treatment for cirrhosis (Huang et al. 2013).

\section{Androgen/AR signaling in hepatitis}

Hepatitis can be caused by viral infection, chemicals, or drug abuse (Williams 2006). Acute hepatitis is usually defined as inflammation lasting for $<6$ months and although most patients present with mild symptoms the acute state can present as severe hepatic failure. Chronic hepatitis, however, lasts longer and patients normally are either asymptomatic or mildly symptomatic.

\section{Androgen/AR signaling in cirrhosis and} hepatitis In addition to toxic/drug and hepatitis virus contributing to hepatitis (Wright \& Lau 1993), cirrhosis may also link to hepatitis since many hepatic patients are also found with cirrhotic liver development (Even et al. 1997). A recent study has found that total serum testosterone is associated with increased risk for developing advanced hepatic fibrosis and advanced hepatic inflammatory activity in hepatitis C virus (HCV)-infected men (White et al. 2012a,b). Theve et al. (2008) found that the anti-androgen flutamide might prevent the development of cirrhosis and hepatitis in mice. Other studies also found a higher incidence of HBV- or HCV-related cirrhosis and HCC among men (DeLoia et al. 1989, Wright \& Lau 1993, Schiff et al. 2003, Chiu et al. 2007). Importantly, direct linkages have been demonstrated between androgen levels (Tanaka et al. 2000) and $A R$ gene polymorphisms (Yu et al. 2000) and the progression of hepatitis and cirrhosis to cancer of the liver.

\section{Androgen/AR signaling in $\mathrm{HBV}$-induced chronic} hepatitis $\mathrm{HBV}$ virus antigens (HBeAg and HBsAg) have been shown to contribute to host immune tolerance to the virus and to be associated with the development of hepatitis. DeLoia et al. (1989) found that the expression of HBsAg was higher in pubescent male mice and that testosterone injection promoted the expression of HBsAg in female mice. In vitro studies further identified the ARE located in the HBV virus, suggesting that androgens might be able to go through AR to bind to the ARE in the HBV virus to modulate $\mathrm{HBV}$ viral titers (Wang et al. 2009). Using ARKO mice that lacked AR expression in hepatocytes, Wu et al. (2010) reported that AR might play key roles in directly regulating HBV replication to influence HBV viral titers, viral particles, and hepatic viral RNA. Results from in vitro cell line studies further confirmed that AR-bound androgen directly binds to ARE in HBV, and that this binding activity is responsible for its transactivation (Wu et al. 2010).

Wu et al. (2010) revealed that male hormones might promote immune tolerance of HBV in liver. Using HBV transgenic mice, Tian et al. (2012) found that male hormones promote HBV virus replication, resulting in higher HBV titers in men than in women and concluded that male hormones but not gender could change the HBsAg and HBx antigens.

Current therapies to improve immune tolerance in patients with HBV-related hepatitis involve administration of interferon to suppress HBV-induced immune activity (Tamori \& Kawada 2012) or regimens that boost immune activity to eliminate HBV-infected hepatocytes (Shimizu 2012). Androgen-deprivation therapy with flutamide or cimentidine, however, yielded controversial results. Although Theve et al. (2008) found that flutamide prevented the development of cirrhosis and hepatitis in mice, other clinical studies have shown that flutamide can lead to further inflammation of the liver (Thole et al. 2004, Manso et al. 2006, Matsuzaki et al. 2006). Wang et al. (2008) reported that the anti-androgen cimentidine resulted in enhanced immune response when administered in conjunction with HBV DNA vaccine by boosting viral clearance. However, Hashimoto et al. (1994) found that cimentidine also resulted in exacerbation of liver damage.

Importantly, in ARKO mouse model studies, Wu et al. (2010) demonstrated that AR, but not androgens, play key roles in the promotion of HBV replication and hepatitis. They found that knockout of AR in hepatocytes resulted in reduced HBV replication. The researchers also found that targeting AR with the newly developed AR degradation enhancer ASC-J9 suppresses HBV-mediated viral replication and the development of HCC in mice (Wu et al. 2010). Figure 1 illustrates the molecular mechanisms governing the effects of androgen/AR on HBV virus replication as well as the positive feedback loop of AR-HBV virus replication.

Published by Bioscientifica Ltd. 


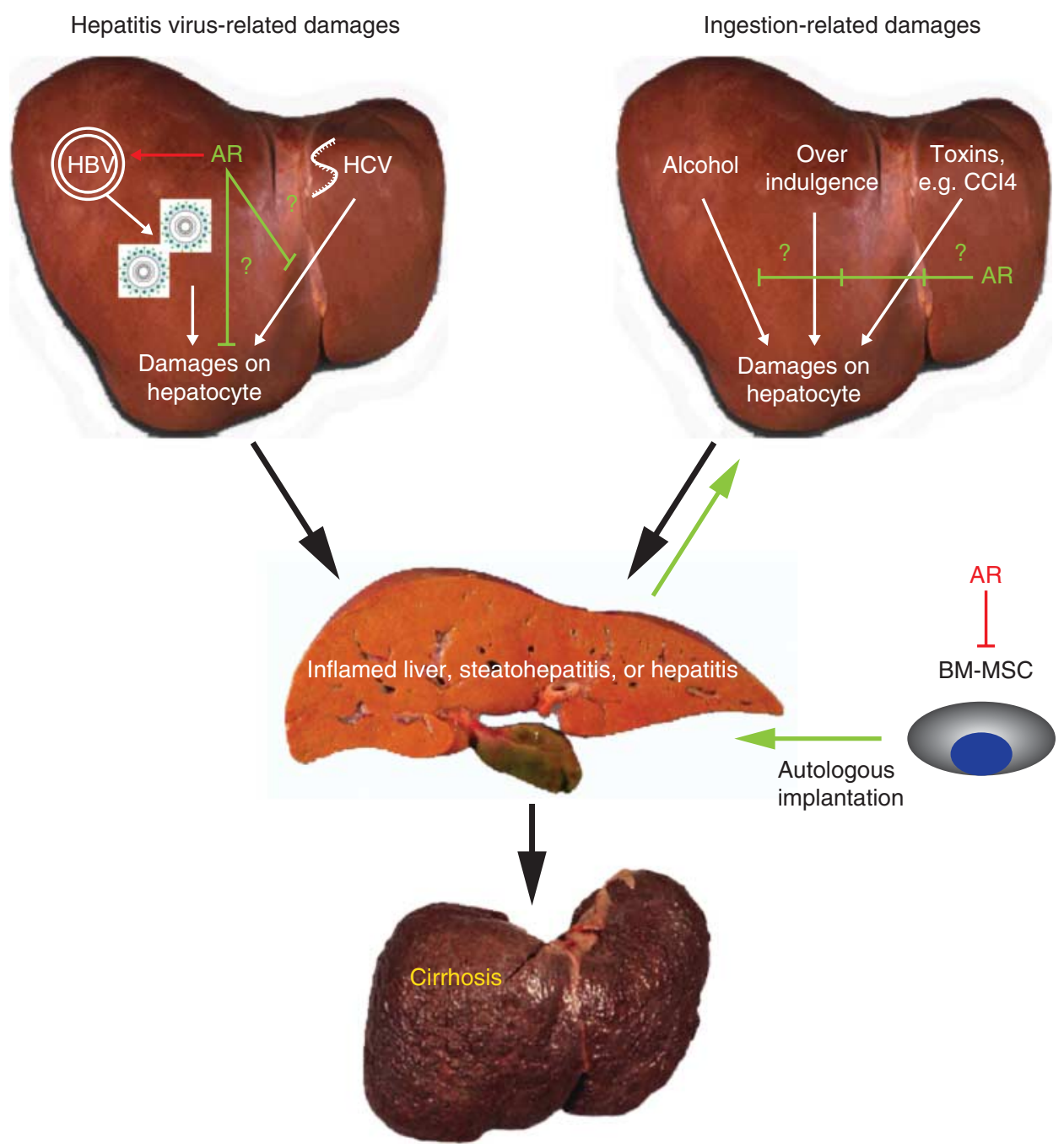

\section{Figure 1}

Androgen/AR roles in noncancerous liver disease progression. In hepatitis virus (HBV and $\mathrm{HCV}$ )-related hepatic inflammation, androgen/AR promotes HBV virus replication, yet, AR might suppress the hepatitis process. On the other hand, AR also plays a suppressive role in the toxin-related liver

\section{Androgen/AR signaling in $\mathrm{HCV}$-induced chronic} hepatitis HCV-mediated hepatitis is often asymptomatic, but chronic infection can lead to scarring of the liver and ultimately to cirrhosis. Chronic HCV infection develops in about $85 \%$ of infected patients and Lee et al. (2011) found that female gender was an independent risk factor for HCV infection. Furthermore, Di Martino et al. (2004) reported that hormone replacement therapy was effective at reducing the incidence of HCC development in HCV-infected women. However, other studies have shown that suppression of estrogen signaling reduces the incidence of HCC development in HCV carriers. Using selective estrogen modulators (SERM), researchers have inflammation process. Moreover, bone marrow-derived mesenchymal stem cells (BM-MSC) can infiltrate into the damage liver; however, AR suppresses the ability of BM-MSC to repair liver damage.

shown that estrogen signaling interferes with the HCV viral cycle (Murakami et al. 2013) and reduces HCVmediated toll-like receptor 7 (TOLR7) signals (Fawzy et al. 2012), indicating that SERM are potential adjuvant antiviral treatments (Furusyo et al. 2012). Interestingly, Huang et al. (2011) reported that male gender was an independent risk factor for the development of liver disease in patients with HCV-related hepatitis. These studies indicate that while women are at greater risk for $\mathrm{HCV}$ infection men are at greater risk of developing HCV-related chronic liver disease.

Kanda et al. (2008) found that HCV viral core antigen could enhance AR transactivation via up-regulation of

Published by Bioscientifica Ltd. 
vascular endothelial growth factor (VEGF) and related Stat 3 activation. It will be interesting to see in the future whether AR has an effect on HCV virology and related liver diseases by modulating the HCV viral core antigen.

The current therapy for HCV hepatitis is a combination of peginterferon alpha-2a and ribavirin with either boceprevir or telaprevir. However, few studies have linked androgen deprivation therapy or anti-AR therapy to $\mathrm{HCV}$. More studies on how AR influences HCV replication are needed before any potential AR-targeted therapy can be developed.

A summary of the roles that androgen/AR play in noncancerous liver diseases is illustrated in Fig. 1.

\section{Part II: androgen/AR signaling in liver cancer}

The American Cancer Society ranked liver cancer as the fifth highest cause of cancer death, with HCC as the most common form of liver neoplasm (Farazi \& DePinho 2006). The etiology of liver cancer includes ingestion of related toxins (e.g., alcohol, aflatoxin B1, or AFB1) and infection with hepatic viruses (HBV, $\mathrm{HCV}$, etc.), which are the major oncogenic factors that contribute to the development of HCC.

Part two of this review will focus on the roles that androgens and their receptors play in the development of HCC and cholangiocarcinoma (CC) and potential therapeutic regimens for patients with HCC that target androgen or AR or both.

\section{Androgen/AR signaling in carcinogen-induced HCC}

The male predominance in HCC suggests that androgen/AR may promote and that estrogens/ERs may suppress hepatocarcinogenesis (Yeh \& Chen 2010). Suppression of carcinogen-induced HCC by estrogen signaling has been shown to regulate MyD88-dependent IL6 production and to trigger cellular innate immunity (Naugler et al. 2007). Although the roles female hormones play in HCC development have been established, that of male hormones are less clear. A number of studies have shown that carcinogen/aflatoxin B1 (AFB1)-induced HCC predominantly affects men (Tejura et al. 1989, Ma et al. 2008, Yeh \& Chen 2010, Li et al. 2012), suggesting that androgen/AR may promote the development of AFB1-induced HCC. Although Yu et al. (2001) showed that male gender was a risk factor for AFB1-related cancer development, Nakatani et al. (2001) revealed that AFB1 intake was associated with an increased risk of HCC with little association with AFB1-DNA adducts or testosterone levels in men. The reasons for these inconsistent findings remain to be identified.
In men, the testes are the major source of systemic androgen levels with the adrenal gland contributing a small amount. In women, ovarian-derived androgen is an important source of systemic androgen levels. Tejura et al. (1989) reported an increase in AR expression in ovariectomized rats after injection of hepatic carcinogen, suggesting a potential female source of androgen in the development of HCC. Early studies found that the change in endogenous or exogenous androgens in male rodents could lead to altered HCC progression (Nakatani et al. 2001). In vitro HCC cell line studies also found that androgen/AR-facilitated cell growth was governed by transcriptional regulation of TGF $\beta 1$ (Yoon et al. 2006).

Using an ARKO mouse model, Ma et al. (2008) found that $\mathrm{AR}$, but not androgens, plays major roles in hepatocarcinogenesis. They also found that the incidence of carcinogen-induced HCC in L-ARKO mice lacking AR in hepatocytes was lower than that in WT mice, even though the serum testosterone levels in both showed little difference (Ma et al. 2008). Using siRNA to knockdown AR or AR-cDNA to overexpress AR, Ma et al. (2008) also found that targeting AR could alter HCC cell growth. Based on their findings, they suggested that hepatic AR might influence the degree of cellular oxidative stress by modulating superoxide dismutase expression and that it might influence the extent of DNA damage repair by modulating p53 and GADD $45 \alpha / \beta$ expression.

Feng et al. (2011) reported that AR might be able to enhance hepatocarcinogenesis by modulating cell cyclerelated kinase- $\beta$-catenin activation signaling. Using systems biological approaches to illustrate the interplay between androgen and estrogen signaling in hepatocarcinogenesis, Li et al. (2012) found that Foxa1 and Foxa2 were the bona fide molecules that governed gender disparity in HCC.

The data suggest, therefore, that androgen/AR signaling promotes hepatocarcinogenesis and HCC development, at least in the early stages. Figure 2 illustrates the androgen/AR roles in carcinogen-induced hepatocarcinogenesis.

\section{Androgen/AR signaling in HBV-induced HCC}

In a nested case-control study, Yuan et al. (1995) concluded that high androgen level is a risk factor for developing HCC in men with chronic HBV infection. Other studies found that higher serum testosterone, increased number of steroid $5 \alpha$-reductase type II (SRD5A2) V89L polymorphisms, and fewer $A R$ gene CAG repeats in exon 1 ( $<23$ repeats) in HBV patients were

Published by Bioscientifica Ltd 


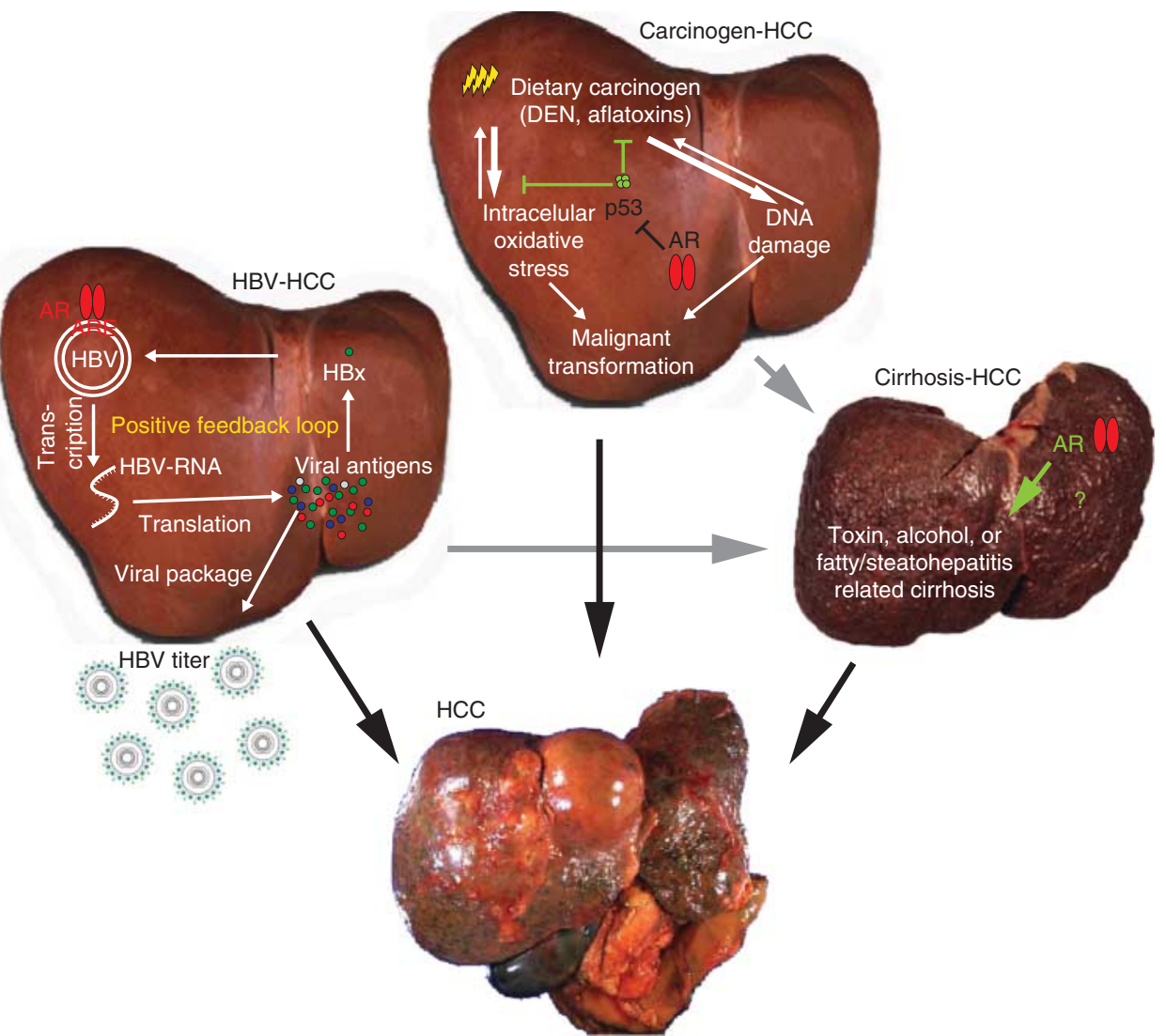

\section{Figure 2}

Androgen/AR signaling in hepatocarcinogenesis. There are three major factors that contribute to the development of liver tumors, e.g., HBV, carcinogens, and cirrhosis. In HBV-related HCC, AR promotes HBV virus replication to increase viral titers, as well as viral antigens to positively feedback to AR transactivation function on HBV replication.

correlated with high risk of HCC (Yu et al. 2000, 2001), suggesting that more active androgen/AR signaling might lead to higher risk of HBV-induced HCC.

Using HBV transgene mice lacking hepatic AR, which were fed sub-minimal doses of the carcinogen DEN, Wu et al. (2010) found that the incidence of HBV-induced HCC was lower among mice with loss of hepatic AR than in WT mice. They revealed that AR enhanced HBV virus replication by binding directly to the HBV core promoter region, which up-regulated the expression of the HBV X antigen (HBx). AR-induced HBx expression subsequently promotes AR transactivation, thereby amplifying its role in hepatic cell transformation. Importantly, AR was also shown to enhance HBV-mediated cell proliferation and to suppress apoptosis (Wu et al. 2010).

Other studies have reported that HBV antigen interacts with $\mathrm{AR}$ to promote HCC initiation and that HBx enhances hepatic cell transformation by interacting
In carcinogen- and DEN-related HCC, AR suppresses $\mathrm{p} 53$ and related cellular oxidative stress and DNA damage repair, thereby promoting hepatocyte transformation. However, it is still unknown how AR is involved in cirrhosisrelated HCC.

with AR signaling (Chiu et al. 2007, Zheng et al. 2007). The mechanism of action governing the effects of HBx on enhanced AR transactivation might involve an increase in phosphorylation of AR rather than binding to ARE sites (Chiu et al. 2007). In contrast, androgen/AR signaling might promote HCC development by enhancing HBx function.

Although some clinical and animal studies have provided evidence that androgen/AR signaling promotes HBV-induced HCC development, other studies have shown that inhibition of androgens has little effect on preventing the progression of hepatitis. Using the LHRH analog triptorelin to suppress testosterone production in male patients with chronic HBV infection, Jilma et al. (1998) found no significant effect on serum HBsAg and HBV-DNA concentrations. Using murine Helicobacter hepaticus infection to study the effects androgen has on chronic hepatitis and HCC progression in mice, Arlin

Published by Bioscientifica Ltd. 
et al. (Rogers et al. 2007) also found little effect of castration on hepatitis and HCC incidence when compared with control mice. Supplementation with dihydrotestosterone also failed to change the outcome. They concluded that an imprinting effect of endogenous androgens might be responsible for chronic hepatitis and HCC in men.

\section{Androgen/AR signaling in HCV-induced HCC}

Although the prevalence of HCV-induced HCC is highest among men, the gender difference in prevalence is not as obvious for HBV-induced HCC. Huang et al. (2011) conducted a prospective cohort study of newly developed HCC and studied the cumulative lifetime incidence rates of HCC in men and women who were positive for both HBV surface antigen (HBsAg) and antibodies against HCV (anti-HCV). They found that there was a significant male predominance in the incidence of HCC for chronic HBV carriers but not for chronic carriers of HCV (Lee et al. 2011). Epidemiological studies have shown polymorphisms of three enzymes involved in androgen and estrogen biosynthesis among anti-HCV positive patients, namely SRD5A2, cytochrome P450c17 $\alpha$ (CYP17), and catechol-O-methyltransferase (Rossi et al. 2003). The researchers found that the frequency of the CYP17 C/C polymorphism in female patients with hepatitis or HCC was higher than that in asymptomatic carriers (Rossi et al. 2003). Kanda et al. (2008) reported that HCV core protein, but not NS5A oncogene, up-regulated AR target genes in Huh7 human HCC cells by augmenting androgen/AR activity. In addition, they found that the HCV-induced increase in AR activity also up-regulated VEGF expression and tube formation in human coronary microvascular endothelial cells (Kanda et al. 2008). Interestingly, Vizoso et al. (2007) examined AR expression in HCVrelated HCC lesions and found little evidence for a linkage between AR or ER expression and HCC progression. Similar negative results also occurred in a study by Wang et al. (2006), who showed that AR expression was not linked to HCV-related HCC. These controversial results indicate that more studies, especially those on HCV mice lacking hepatic AR, are needed to better understand the roles AR plays in HCV-induced HCC.

\section{Androgen/AR signaling in cirrhosis-induced HCC}

Regardless of the etiological factors, cirrhosis and HCC progress at unequal rates in the two sexes, with more frequent disease in men than in women
(Giannitrapani et al. 2006). In addition, Tanaka et al. (2000) found that elevated serum testosterone, together with decreased serum estrogens, may promote the development of HCC in patients with cirrhosis.

Although an increase in HCC incidence was reported in patients with NAFLD and cirrhosis (White et al. 2012a), the evidence of direct linkage of androgen/AR signaling in NAFLD with cirrhosis-induced HCC remains unclear.

A direct positive linkage between androgen/AR signaling and the progression of HBV-cirrhosis to HCC is still lacking (Iloeje et al. 2012). Interestingly, Gong et al. (2010) found that loss of an X chromosome might result in altered transformation of hepatocytes in patients with HBV-induced cirrhosis, suggesting the potential linkage between AR loss and the initiation of HCC. Furthermore, Rossi et al. (2003) reported that higher CYP17 activity might increase serum androgen levels and that these increased levels might be associated with risk for HCV-related cirrhosis.

The androgen/AR roles in HBV-, carcinogen-, and cirrhosis-related hepatocarcinogenesis are summarized and illustrated in Fig. 2.

\section{Androgen/AR signaling in HCC progression and invasion}

Although there is sound evidence that androgen/AR promote hepatocarcinogenesis and HCC development in the early stages, there is less evidence showing a direct link between androgen/AR signaling and HCC progression in advanced stages. Yuan et al. (1995) reported that testosterone levels were higher in men than in women with advanced HCC, indicating that androgen might play positive roles in advanced HCC. In addition, Kew et al. (1977) found that testosterone levels were positively correlated with survival in patients with HCC.

However, the correlation between AR expression and progression of HCC remains controversial (Kalra et al. 2008). Nagasue et al. (1995) reported up-regulation of AR protein in peripheral tumor lesions, while Tavian et al. (2002) reported downregulation of AR mRNA in poorly differentiated HCC lesions. The reason for the inconsistencies in results is unknown. It could be due to small sampling size and different measurement methods. However, the reason is most likely misclassification of samples. Most of the studies failed to differentiate HCC samples by stage, tumor size, and malignant cellularity. Ma et al. (2012b) found that AR was up-regulated only in tumors smaller than $3 \mathrm{~cm}$. They also found little AR expression in severe HCC lesions, which was consistent with results from Zhu et al. (2011), which showed that AR

Published by Bioscientifica Ltd. 
was expressed only in the tumor margins and not in the tumor centers.

In a study using L-ARKO mice lacking hepatic AR with carcinogen-induced HCC, Ma et al. (2012b) demonstrated that mice with loss of hepatic AR developed more malignant tumors, had poorer survival, and had a higher incidence of metastatic lung tumors. They further used in vitro HCC cell lines to investigate whether knock down of hepatic AR or overexpression of AR altered HCC cell migration and invasion and found that AR alters HCC invasion by indirectly suppressing NFKB. These results indicate that AR might suppress HCC metastasis in the advanced stage of HCC.

HCC cell survival in the detached environment (circulation) and the ability to metastasize to distant organs or micrometastasize to neighboring liver tissues is critical for malignant progression of HCC in the advanced stage. A recent report revealed that AR enhanced HCC cell anoikis by suppressing p38 phosphorylation (Ma et al. 2012b), raising the possibility that detecting $\mathrm{AR}$ expression in circulating HCC-tumor cells could be a diagnostic marker for HCC recurrence/invasion after curative surgery.

Taken together, the ability of AR to enhance HCC cell anoikis and suppress HCC cell invasion suggests that $\mathrm{AR}$ might function as a suppressor of metastasis in late-stage HCC.

\section{Cholangiocarcinoma}

Cholangiocarcinoma (CC), a liver tumor arising from the epithelial cells (cholangiocytes) lining the biliary tree, is characterized by poor prognosis and poor response to current therapies (Marsh Rde et al. 2012a,b, Valero et al. 2012). The incidence of and mortality associated with CC are increasing worldwide and an etiological study found that the daily ingestion of germs, including Helicobacter spp., and parasites might contribute to the development of CC (Samaras et al. 2010). Liossi et al. (1988) found $17 \beta$-estradiol $\left(\mathrm{E}_{2}\right)$, but not testosterone, immunoactivity in CC lesions, suggesting potential protective/redundant roles of male hormones in CC progression. Other studies found that estradiol levels were higher among patients with CC than among patients with HCC or cirrhosis (Kuper et al. 2001a). Further studies found that estrogenic signaling might promote CC progression via the estrogen receptor alpha (ER $\alpha)$-AKT pathway (Alvaro et al. 2006) and up-regulation of VEGF (Mancino et al. 2009), and that $\mathrm{E}_{2}$ and $\mathrm{ER} \alpha$ levels were increased in male CC patients.

\section{Potential AR-targeted therapies for HCC}

Dual and opposite roles of AR in HCC progression Hepatic AR plays positive roles in hepatocarcinogenesis and in the early development of HCC (Nagasue et al. 1995, Tavian et al. 2002), but have been shown to play negative roles in the advanced stage of HCC (Nagasue et al. 1995, Tavian et al. 2002). A clear understanding of the mechanisms governing these opposite and dual functions of AR in HCC progression might lead to the development of different therapeutic approaches for HCC at different stages (see sections 'ASC-J9, a new AR-targeted therapy for earlystage HCC' and 'AR-targeted therapy in combination with other therapeutic agents as treatment for late-stage HCC').

\section{Controversial results of using anti-androgens to} battle HCC The dual and opposite roles of AR during HCC progression might also explain the controversial results of past clinical studies involving the targeting of androgens (but not AR) to battle HCC. Results from several studies on the use of anti-androgens to manage HCC remain controversial (Hépatocellulaire 2004, Di Maio et al. 2008). For example, in a large cohort-nested case-control study, Yuan et al. (1995) found that serum testosterone levels in HCC patients were significantly higher than those in nonHCC controls. Ex vivo studies using human HCC primary cells also demonstrated a positive correlation between androgen/AR signaling and HCC progression (Yu et al. 1997). Recent studies have also suggested that HBx protein might function as a coactivator to promote AR-mediated anchorage-independent cell growth via AR-HBx protein interaction (Chiu etal. 2007, Zheng etal. 2007). Importantly, clinical studies using the anti-androgen cyproterone acetate (300 mg daily) showed some positive improvement in HCC cell growth (Forbes et al. 1987). Similarly, the results of an ex vivo study using the anti-androgen flutamide showed that flutamide suppressed androgen-induced HCC cell growth (Jie et al. 2007). In contrast, other studies found that serum testosterone levels were lower in HCC patients than in nonHCC control patients (Lampropoulou-Karatzas et al. 1993, Kuper et al. 2001b). A small-scale phase II clinical trial of flutamide failed to show improvement in HCC patient survival (Chao et al. 1996). A similar result was found in a large-scale population study using leuprorelin and flutamide (Hépatocellulaire 2004).

There are several possible explanations for the controversial findings among clinical trials and basic studies. One of the explanations is that most of the antiandrogen trials included patients with advanced stage, unresectable HCC. Anti-androgens only suppress a small

Published by Bioscientifica Ltd. 
portion of fast growing cancer cells, but not poorly differentiated lesions. Another explanation is that AR expression is low in advanced HCC; therefore, antiandrogens no longer exert tumor suppressive effects. The controversial results of the effects of androgens or antiandrogens on HCC progression suggest that targeting androgens to suppress HCC progression might have limited value. Therefore, targeting AR may represent a better therapeutic approach to battle HCC progression.

\section{ASC-J9, a new AR-targeted therapy for early-stage} HCC Using testicular feminized mice that lack AR in the whole body with little serum testosterone, Kemp \& Drinkwater (1989) found that AR expression in liver tumors was lower than that in the surrounding normal liver tissue. They concluded that testosterone might function through AR to promote HCC progression, and suggested that either testosterone or AR might be able to promote HCC progression. Using GARKO mice that lack AR in the whole body with little serum testosterone,
Ma et al. (2008) also showed a reduced incidence of HCC development, cancer growth, and apoptosis.

However, since it was impossible to distinguish between the effects of androgen and the effects of AR in the two mouse models mentioned earlier, Ma et al. developed a new mouse model that only lacks hepatic AR (L-ARKO) with little change in serum testosterone. They found that the suppressive effects of AR on hepatocarcinogenesis in mice without hepatic AR were similar to those observed in GARKO mice, suggesting that AR, and not androgens, might play key roles in the promotion of hepatotumorigenesis and the development of HCC (Ma et al. 2008).

These results provide a new therapeutic approach for treating patients with early-stage HCC. Using a newly developed AR degradation enhancer, ASC-J9, which has been shown to degrade AR in selected cells with few side effects (Miyamoto et al. 2007, Yang et al. 2007, Lai et al. 2012, 2013), Ma et al. (2008) found that targeting AR could suppress HCC progression in a carcinogen-induced HCC mouse model and in an HBV-lowDEN-induced HCC

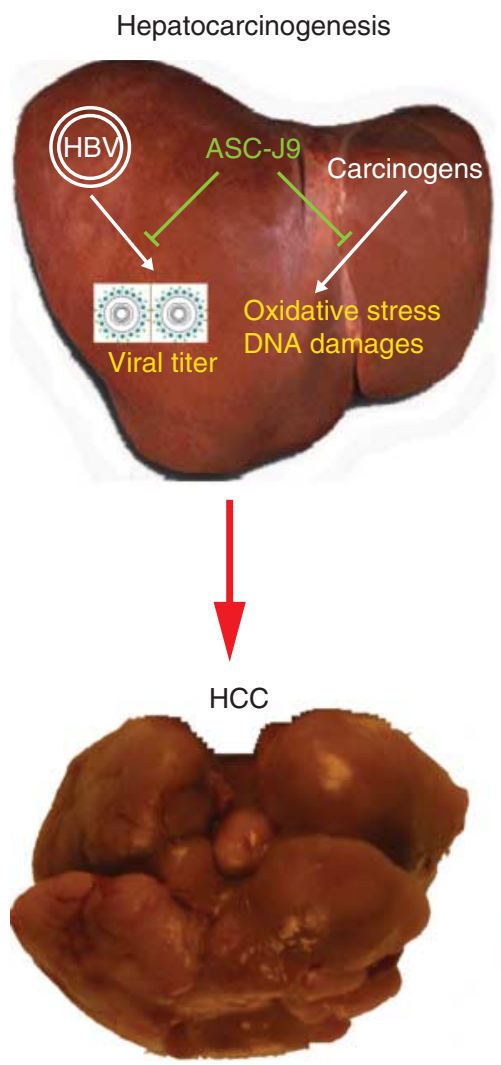

Cirrhosis Advanced HCC
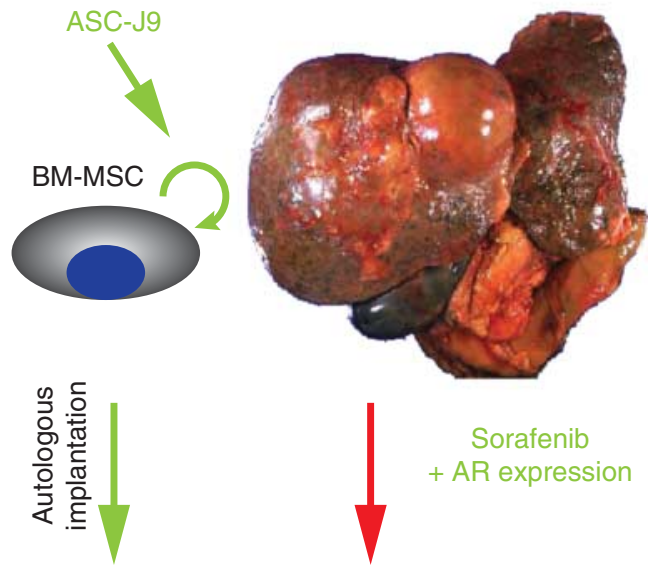

Cirrhosis

Metastasis
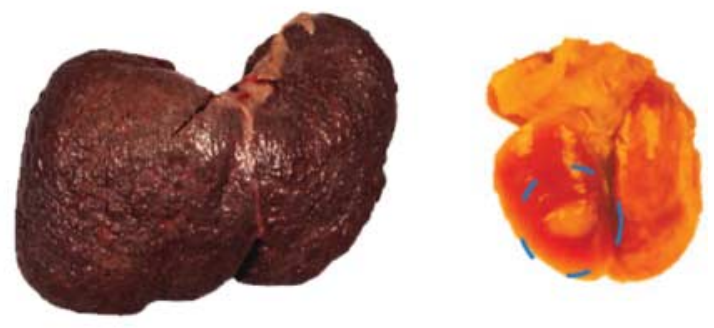

Figure 3

Novel therapeutic strategy targeting AR to battle liver diseases. In the early stage of HCC development, targeting AR using ASC-J9 might suppress early cancer progression. And in the cirrhotic liver, ASC-J9 applied to BM-MSC for autologus implantation might be effective against cirrhosis. At last, treatment of patients with advanced-stage HCC with Sorafenib and expressing $A R$ in the liver might improve the therapeutic efficiency of Sorafenib at reducing the incidence of metastasis or recurrence. http://erc.endocrinology-journals.org DOI: 10.1530/ERC-13-0283
(C) 2014 Society for Endocrinology Printed in Great Britain
Published by Bioscientifica Ltd 
mouse model (Wu et al. 2010). These findings suggest that ASC-J9 might be an effective therapy for stage I or grade 1 HCC. Considering the fact that the rate of recurrence of HCC is as high as $60 \%$ in patients with HCC stage I-II or grade 1-2 disease who are treated with preventive chemotherapy or transcatheter arterial chemoembolization (Lim et al. 2012, Jung et al. 2013), targeting the remaining AR-induced HCC cells via ASC-J9 at the early stage of HCC may prevent or delay the recurrence of tumors after treatment. The impact of using ASC-J9 to suppress HBV-lowDEN-induced HCC may be huge, especially in countries with a high rate of HBV infection, as there have been around 522400 new liver cancer patients yearly in the USA (Jemal et al. 2011) and Jemal et al. (2011) also reported that $60 \%$ of over 1 million newly identified liver cancer patients yearly were from HBV infections in the Eastern and South-Eastern Asia, especially in China, considering the HBV-infected population in China is around $8 \%$ of the over 1.3 billion people. The value of any successful therapy to prevent or delay the development of HCC from HBV hepatitis in these HBV-hepatitis patients can be also huge.

\section{AR-targeted therapy in combination with other therapeutic agents as treatment for late-stage} HCC In the advanced stages of HCC, chemotherapy with Sorafenib has been shown to have beneficial effects in selected patients (Llovet et al. 2008, Yau et al. 2009). Increasing the effectiveness of therapies that benefit more
HCC patients is challenging and needed. Ma et al. (2012b) found that AR could suppress HCC metastasis by modulating p38. They also found that the addition of functional AR in SKhep1 and HepG2 HCC cells to decrease p38 enhanced the effectiveness of Sorafenib against HCC cells in later stages of development. Importantly, results from tail-vein injection cancer metastasis mouse model showed using a much lower Sorafenib dosage (30 mg/kg per mouse) with combined therapy to increase AR expression could lead to similar therapeutic effects as compared with the higher dosage used in the Bayer preclinical trial (40-60 mg/kg per mouse) (Hoshino-Yoshino et al. 2011). This suggests that pre-screening for higher expression of hepatic AR in patients with advanced HCC may help to increase the efficacy of treatment with Sorafenib. Alternatively, a new combinational therapy with Sorafenib and some compounds to enhance the functional AR expression may be developed to battle HCC at later advanced stages in the future.

Together, the findings of differential androgen/AR roles in early HCC development vs advanced HCC progression provided insights for targeting AR in these two stages of cancers, which is illustrated in Fig. 3.

\section{Summary and future prospects}

Androgen/AR signaling plays different roles in various liver diseases. Androgen/AR signaling suppresses the development of steatosis and may also suppress the development of cirrhosis. In HBV-induced hepatitis,

Table 1 Summary of the androgen/AR roles in liver diseases

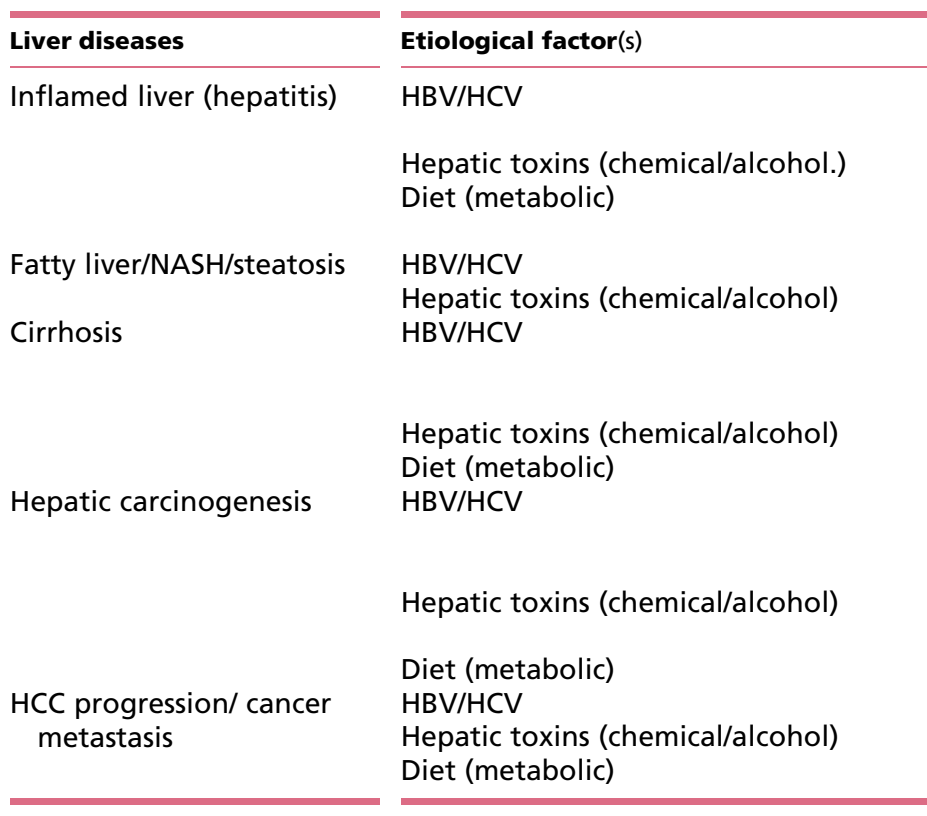

Androgen/AR roles
Promoter (Jacqueson et al. 1978, Kanda et al. 2008,
Theve et al. 2008, White et al. 2012a,b)
Protective effect (Jacqueson et al. 1978)
Promoter (Vassilatou et al. 2010, Schwingel et al 2011a,b,
Jones et al. 2012)
Suppressor (Lin et al. 2005, 2008)
Promoter (Chow et al. 2011)/suppressor (Zhang et al. 2013)
Promoter/suppressor (DeLoia et al. 1989, Wright \& Lau 1993,
Tanaka et al. 2000, Yu et al. 2000, Schiff et al. 2003,
Chiu et al. 2007, Wang et al. 2009, Wu et al. 2010)
Inconclusive (Thole et al. 2004, Rambaldi \& Gluud 2006)
Unknown
Promoter/suppressor (Yu et al. 2000, 2001, Chiu et al. 2007,
Zhang et al. 2007, Kanda et al. 2008, Wang et al. 2008, Wu
et al. 2010, Huang et al. 2011)
Promoter (Tejura et al. 1989, Rossi et al. 2003, Ma et al. 2008,
Li et al. 2012)
Unknown
Unknown
Unknown
Suppressor (Tavian et al. 2002, Zhu et al. 2011, Ma et al. (2012b))


androgen/AR signaling enhances HBV replication and promotes HBV- and carcinogen-induced hepatotumorigenesis and HCC development. However, in the advanced stages of HCC progression, androgen/AR signaling suppresses HCC metastasis. In Table 1, we have summarized the overall androgen/AR signaling effects in liver disease.

There is mounting evidence that the effects of androgen are not equal to those of AR on HCC progression and that targeting AR instead of targeting androgens may lead to better therapies for patients with HCC. Additional studies are needed to uncover how AR influences individual infiltrating cells and their interaction within the HCC microenvironment (Ma et al. 2012a).

Although hepatocytes comprise more than $85 \%$ of all cells in normal livers, the cancerous liver presents with an increased number of infiltrating immune cells (Doumba et al. 2013, Guo et al. 2013), including dendrocytes (Butterfield 2004), monocytes/macrophages (Shirabe et al. 2012), CD4/8 + T cells (Guo et al. 2013), neutrophils (Motomura et al. 2013), B cells (Chen et al. 2012), and mast cells (Ju et al. 2009). Other cells in the liver, such as endothelial cells (Sato \& Mori 2011) or BM-MSCs (Garcia et al. 2011), may also be altered due to chronic inflammation or tumorigenesis. Ma et al. found that infiltration of monocytes/macrophages might alter the growth and invasion patterns of HCC and that targeting AR in HCC might reduce the infiltration of monocytes/macrophages, thereby suppressing monocyte/macrophage-mediated cancer growth (Wen-Lung Ma, Yin-Yi Chen, Chawnshang Chang, 2013, unpublished observations). Huang et al. (2013) also revealed that infiltrating BM-MSCs in the cirrhotic liver might result in enhanced liver repair and subsequent improvement in liver function. It will be interesting to see whether targeting AR in BM-MSCs suppresses or prevents the progression of cirrhosis to HCC.

Many studies have focused on sex hormone signaling to try to explain the gender difference associated with HCC. In a recent review article, Ruggieri et al. (2010) provided an abundance of evidence that estrogens inhibit IL6 production by suppressing $\mathrm{NF \kappa B} / \mathrm{MyD} 88$ and that they also reduce cellular oxidative stress. However, they also found that androgen signaling promotes the VEGF/Stat3 pathway and suppresses p53-mediated antitumor effects. Therefore, there appears to be a crossover of estrogen and androgen signals in the regulation of cellular oxidative stresses.

In summary, the dual yet opposite roles of AR in early HCC initiation vs later advanced stages and findings developing new and differential therapeutic approaches via targeting AR to battle HCC at different stages may help us to better battle the HCC.

\section{Declaration of interest}

ASC-J9 was patented by the University of Rochester, the University of North Carolina, and AndroScience, and then licensed to AndroScience. Both the University of Rochester and C Chang own royalties and equity in AndroScience.

\section{Funding}

This work was supported by NIH Grant CA127300, George Whipple Professorship Endowment at University of Rochester to C Chang, and Taiwan National Science Council grant (NSC101-2314-B-039-027-MY3), and National Health Research Institution grant (NHRI-EX102-10214BC) to W-L Ma.

\section{Acknowledgements}

The authors thank Prof. Charles Sparks (University of Rochester) for critical review, discussion, and suggestions. The authors also thank Karen Wolf and Jeffery Conrad for English editing of the manuscript.

\section{References}

Alvaro D, Barbaro B, Franchitto A, Onori P, Glaser SS, Alpini G, Francis H, Marucci L, Sterpetti P, Ginanni-Corradini S et al. 2006 Estrogens and insulin-like growth factor 1 modulate neoplastic cell growth in human cholangiocarcinoma. American Journal of Pathology 169 877-888. (doi:10.2353/ajpath.2006.050464)

Aspinall EJ, Hawkins G, Fraser A, Hutchinson SJ \& Goldberg D 2011 Hepatitis B prevention, diagnosis, treatment and care: a review. Occupational Medicine 61 531-540. (doi:10.1093/occmed/kqr136)

Baig S 2009 Gender disparity in infections of hepatitis B virus. Journal of the College of Physicians and Surgeons Pakistan 19 598-600.

Bluemn EG \& Nelson PS 2012 The androgen/androgen receptor axis in prostate cancer. Current Opinion in Oncology 24 251-257. (doi:10.1097/ CCO.0b013e32835105b3)

Bradbury MW 2006 Lipid metabolism and liver inflammation. I. Hepatic fatty acid uptake: possible role in steatosis. American Journal of Physiology. Gastrointestinal and Liver Physiology 290 G194-G198. (doi:10.1152/ajpgi.00413.2005)

Butterfield LH 2004 Immunotherapeutic strategies for hepatocellular carcinoma. Gastroenterology 127 S232-S241. (doi:10.1053/j.gastro.2004.09.038)

Chan AC, Chok KS, Yuen WK, Chan SC, Poon RT, Lo CM \& Fan ST 2011 Impact of antiviral therapy on the survival of patients after major hepatectomy for hepatitis B virus-related hepatocellular carcinoma. Archives of Surgery 146 675-681. (doi:10.1001/archsurg.2011.125)

Chang CS, Kokontis J \& Liao ST 1988 Molecular cloning of human and rat complementary DNA encoding androgen receptors. Science $\mathbf{2 4 0}$ 324-326. (doi:10.1126/science.3353726)

Chao Y, Chan WK, Huang YS, Teng HC, Wang SS, Lui WY, Whang-Peng J \& Lee SD 1996 Phase II study of flutamide in the treatment of hepatocellular carcinoma. Cancer 77 635-639. (doi:10.1002/ (SICI)1097-0142(19960215)77:4<635::AID-CNCR8 > 3.0.CO;2-F)

Chen Y, Xiang LX, Shao JZ, Pan RL, Wang YX, Dong XJ \& Zhang GR 2010 Recruitment of endogenous bone marrow mesenchymal stem cells towards injured liver. Journal of Cellular and Molecular Medicine 14 1494-1508. (doi:10.1111/j.1582-4934.2009.00912.x)

Chen T, Song D, Min Z, Wang X, Gu Y, Wei B, Yao J, Chen K, Jiang Z, Xie H et al. 2012 Perioperative dynamic alterations in peripheral regulatory $\mathrm{T}$ and B cells in patients with hepatocellular carcinoma. Journal of Translational Medicine 10 14. (doi:10.1186/1479-5876-10-14)

Chiu CM, Yeh SH, Chen PJ, Kuo TJ, Chang CJ, Chen PJ, Yang WJ \& Chen DS 2007 Hepatitis B virus X protein enhances androgen receptorresponsive gene expression depending on androgen level. PNAS 104 2571-2578. (doi:10.1073/pnas.0609498104) 
Chow JD, Jones ME, Prelle K, Simpson ER \& Boon WC 2011 A selective estrogen receptor $\alpha$ agonist ameliorates hepatic steatosis in the male aromatase knockout mouse. Journal of Endocrinology 210 323-334. (doi:10.1530/JOE-10-0462)

Cicero AF, Tartagni E \& Ertek S 2012 Metformin and its clinical use: new insights for an old drug in clinical practice. Archives of Medical Science $\mathbf{8}$ 907-917. (doi:10.5114/aoms.2012.31622)

Claessens F, Verrijdt G, Schoenmakers E, Haelens A, Peeters B, Verhoeven G \& Rombauts W 2001 Selective DNA binding by the androgen receptor as a mechanism for hormone-specific gene regulation. Journal of Steroid Biochemistry and Molecular Biology 76 23-30. (doi:10.1016/S09600760(00)00154-0)

Cornell RP, Liljequist BL \& Bartizal KF 1990 Depressed liver regeneration after partial hepatectomy of germ-free, athymic and lipopolysaccharide-resistant mice. Hepatology 11 916-922. (doi:10.1002/hep. 1840110603)

Cressman DE, Greenbaum LE, Haber BA \& Taub R 1994 Rapid activation of post-hepatectomy factor/nuclear factor $\kappa \mathrm{B}$ in hepatocytes, a primary response in the regenerating liver. Journal of Biological Chemistry $\mathbf{2 6 9}$ 30429-30435.

Cressman DE, Greenbaum LE, DeAngelis RA, Ciliberto G, Furth EE, Poli V \& Taub R 1996 Liver failure and defective hepatocyte regeneration in interleukin-6-deficient mice. Science 274 1379-1383. (doi:10.1126/ science.274.5291.1379)

DeLoia JA, Burk RD \& Gearhart JD 1989 Developmental regulation of hepatitis B surface antigen expression in two lines of hepatitis B virus transgenic mice. Journal of Virology 63 4069-4073.

Dima A, Marinescu AG \& Dima AC 2012 Non-alcoholic fatty liver disease and the statins treatment. Romanian Journal of Internal Medicine 50 19-25.

Di Maio M, Daniele B, Pignata S, Gallo C, De Maio E, Morabito A, Piccirillo MC \& Perrone F 2008 Is human hepatocellular carcinoma a hormoneresponsive tumor? World Journal of Gastroenterology 14 1682-1689. (doi:10.3748/wjg.14.1682)

Di Martino V, Lebray P, Myers RP, Pannier E, Paradis V, Charlotte F, Moussalli J, Thabut D, Buffet C \& Poynard T 2004 Progression of liver fibrosis in women infected with hepatitis C: long-term benefit of estrogen exposure. Hepatology 40 1426-1433. (doi:10.1002/hep.20463)

Doumba PP, Nikolopoulou M, Gomatos IP, Konstadoulakis MM \& Koskinas J 2013 Co-culture of primary human tumor hepatocytes from patients with hepatocellular carcinoma with autologous peripheral blood mononuclear cells: study of their in vitro immunological interactions. BMC Gastroenterology 13 17. (doi:10.1186/1471-230X-13-17)

El-Ansary M, Abdel-Aziz I, Mogawer S, Abdel-Hamid S, Hammam O, Teaema S \& Wahdan M 2012 Phase II trial: undifferentiated versus differentiated autologous mesenchymal stem cells transplantation in Egyptian patients with HCV induced liver cirrhosis. Stem Cell Research $\mathbf{8}$ 972-981. (doi:10.1007/s12015-011-9322-y)

Even C, Launoy G, Collet T, Duval O, Piquet MA, Rougereau A, Verwaerde JC \& Dao T 1997 Epidemiology of hepatocellular carcinoma in the Department of Calvados. Gastroenterologie Clinique et Biologique 21 450-458.

Fang B, Shi M, Liao L, Yang S, Liu Y \& Zhao RC 2004 Systemic infusion of FLK1(+) mesenchymal stem cells ameliorate carbon tetrachlorideinduced liver fibrosis in mice. Transplantation 78 83-88. (doi:10.1097/ 01.TP.0000128326.95294.14)

Farazi PA \& DePinho RA 2006 The genetic and environmental basis of hepatocellular carcinoma. Discovery Medicine 6 182-186.

Fawzy IO, Negm M, Ahmed R, Esmat G, Hamdi N \& Abdelaziz AI 2012 Tamoxifen alleviates hepatitis $\mathrm{C}$ virus-induced inhibition of both tolllike receptor 7 and JAK-STAT signalling pathways in PBMCs of infected Egyptian females. Journal of Viral Hepatitis 19 854-861. (doi:10.1111/ j.1365-2893.2012.01612.x)

Feng H, Cheng AS, Tsang DP, Li MS, Go MY, Cheung YS, Zhao GJ, Ng SS, Lin MC, Yu J et al. 2011 Cell cycle-related kinase is a direct androgen receptor-regulated gene that drives $\beta$-catenin/T cell factor-dependent hepatocarcinogenesis. Journal of Clinical Investigation 121 3159-3175. (doi:10.1172/JCI45967)

http://erc.endocrinology-journals.org DOI: 10.1530/ERC-13-0283
(C) 2014 Society for Endocrinology Printed in Great Britain
Forbes A, Wilkinson ML, Iqbal MJ, Johnson PJ \& Williams R 1987 Response to cyproterone acetate treatment in primary hepatocellular carcinoma is related to fall in free $5 \alpha$-dihydrotestosterone. European Journal of Cancer \& Clinical Oncology 23 1659-1664. (doi:10.1016/02775379(87)90446-9)

Furusyo N, Ogawa E, Sudoh M, Murata M, Ihara T, Hayashi T, Ikezaki H, Hiramine S, Mukae H, Toyoda K et al. 2012 Raloxifene hydrochloride is an adjuvant antiviral treatment of postmenopausal women with chronic hepatitis C: a randomized trial. Journal of Hepatology $\mathbf{5 7}$ 1186-1192. (doi:10.1016/j.jhep.2012.08.003)

Garcia MG, Bayo J, Bolontrade MF, Sganga L, Malvicini M, Alaniz L, Aquino JB, Fiore E, Rizzo MM, Rodriguez A et al. 2011 Hepatocellular carcinoma cells and their fibrotic microenvironment modulate bone marrow-derived mesenchymal stromal cell migration in vitro and in vivo. Molecular Pharmaceutics 8 1538-1548. (doi:10.1021/ mp200137c)

Giannitrapani L, Soresi M, La Spada E, Cervello M, D'Alessandro N \& Montalto G 2006 Sex hormones and risk of liver tumor. Annals of the New York Academy of Sciences 1089 228-236. (doi:10.1196/annals. 1386.044)

Gluud C 1988 Testosterone and alcoholic cirrhosis. Epidemiologic, pathophysiologic and therapeutic studies in men. Danish Medical Bulletin 35 564-575.

Gluud C, Christoffersen P, Eriksen J, Wantzin P \& Knudsen BB 1987 No effect of long-term oral testosterone treatment on liver morphology in men with alcoholic cirrhosis. American Journal of Gastroenterology $\mathbf{8 2}$ 660-664.

Gong L, Li YH, Su Q, Chu X \& Zhang W 2010 Clonality of nodular lesions in liver cirrhosis and chromosomal abnormalities in monoclonal nodules of altered hepatocytes. Histopathology 56 589-599. (doi:10.1111/j.1365-2559.2010.03523.x)

Green GR 1977 Mechanism of hypogonadism in cirrhotic males. Gut 18 843-853. (doi:10.1136/gut.18.10.843)

Guo CL, Yang HC, Yang XH, Cheng W, Dong TX, Zhu WJ, Xu Z \& Zhao L 2013 Associations between infiltrating lymphocyte subsets and hepatocellular carcinoma. Asian Pacific Journal of Cancer Prevention 13 5913-5917.

Guy J \& Yee HF Jr 2009 Health disparities in liver disease: time to take notice and take action. Hepatology 50 309-313. (doi:10.1002/hep. 22942)

Haider A, Gooren LJ, Padungtod P \& Saad F 2010 Improvement of the metabolic syndrome and of non-alcoholic liver steatosis upon treatment of hypogonadal elderly men with parenteral testosterone undecanoate. Experimental and Clinical Endocrinology \& Diabetes 118 167-171. (doi:10.1055/s-0029-1202774)

Hashimoto F, Davis RL \& Egli D 1994 Hepatitis following treatments with famotidine and then cimetidine. Annals of Pharmacotherapy 28 37-39.

Hashizume H, Sato K, Takagi H, Hirokawa T, Kojima A, Sohara N, Kakizaki S Mochida Y, Shimura T, Sunose Y et al. 2007 Primary liver cancers with nonalcoholic steatohepatitis. European Journal of Gastroenterology \& Hepatology 19 827-834. (doi:10.1097/MEG.0b013e3282748ef2)

Hépatocellulaire. GdEedTdC 2004 Randomized trial of leuprorelin and flutamide in male patients with hepatocellular carcinoma treated with tamoxifen. Hepatology 40 1361-1369. (doi:10.1002/hep.20474)

Heron M, Hoyert DL, Murphy SL, Xu J, Kochanek KD \& Tejada-Vera B 2009 Deaths: final data for 2006. National Vital Statistics Report 57 1-134.

Hoshino-Yoshino A, Kato M, Nakano K, Ishigai M, Kudo T \& Ito K 2011 Bridging from preclinical to clinical studies for tyrosine kinase inhibitors based on pharmacokinetics/pharmacodynamics and toxicokinetics/toxicodynamics. Drug Metabolism and Pharmacokinetics 26 612-620. (doi:10.2133/dmpk.DMPK-11-RG-043)

Huang YT, Jen CL, Yang HI, Lee MH, Su J, Lu SN, Iloeje UH \& Chen CJ 2011 Lifetime risk and sex difference of hepatocellular carcinoma among patients with chronic hepatitis B and C. Journal of Clinical Oncology 29 3643-3650. (doi:10.1200/JCO.2011.36.2335) 
Huang CK, Lee SO, Lai KP, Ma WL, Lin TH, Tsai MY, Luo J \& Chang C 2013 Targeting androgen receptor in bone marrow mesenchymal stem cells leads to better transplantation therapy efficacy in liver cirrhosis. Hepatology 57 1550-1563. (doi:10.1002/hep.26135)

Iloeje UH, Yang HI \& Chen CJ 2012 Natural history of chronic hepatitis B: what exactly has REVEAL revealed? Liver International 32 1333-1341. (doi:10.1111/j.1478-3231.2012.02805.x)

Jacqueson A, Thevenin M, Warnet JM, Claude JR \& Truhaut R 1978 Comparative study of the protective effect of an anabolic steroid. The 19-nortestosterone-phenylpropionate (19 NTPP), on liver steatosis induced by Amanita phalloides and white phosphorus in rats. Archives of Toxicology. Supplement 1 193-196.

Jemal A, Bray F, Center MM, Ferlay J, Ward E \& Forman D 2011 Global cancer statistics. CA: A Cancer Journal for Clinicians 61 69-90. (doi:10.3322/caac.20107)

Jilma B, Eichler HG, Koppl C, Weber B, Pidlich JP, Ferenci P \& Muller C 1998 Effects of testosterone suppression on serum levels of hepatitis B surface antigen and HBV-DNA in men. Liver 18 162-165. (doi:10.1111/ j.1600-0676.1998.tb00144.x)

Jones H, Sprung VS, Pugh CJ, Daousi C, Irwin A, Aziz N, Adams VL, Thomas EL, Bell JD, Kemp GJ et al. 2012 Polycystic ovary syndrome with hyperandrogenism is characterized by an increased risk of hepatic steatosis compared to nonhyperandrogenic PCOS phenotypes and healthy controls, independent of obesity and insulin resistance. Journal of Clinical Endocrinology and Metabolism 97 3709-3716. (doi:10.1210/jc.2012-1382)

Ju MJ, Qiu SJ, Gao Q, Fan J, Cai MY, Li YW \& Tang ZY 2009 Combination of peritumoral mast cells and T-regulatory cells predicts prognosis of hepatocellular carcinoma. Cancer Science 100 1267-1274. (doi:10.1111/ j.1349-7006.2009.01182.x)

Jung ES, Kim JH, Yoon EL, Lee HJ, Lee SJ, Suh SJ, Lee BJ, Seo YS, Yim HJ Seo TS et al. 2013 Comparison of the methods for tumor response assessment in patients with hepatocellular carcinoma undergoing transarterial chemoembolization. Journal of Hepatology $\mathbf{5 8} 1181-1187$. (doi:10.1016/j.jhep.2013.01.039)

Kalra M, Mayes J, Assefa S, Kaul AK \& Kaul R 2008 Role of sex steroid receptors in pathobiology of hepatocellular carcinoma. World Journal of Gastroenterology 14 5945-5961. (doi:10.3748/wjg.14.5945)

Kanda T, Steele R, Ray R \& Ray RB 2008 Hepatitis C virus core protein augments androgen receptor-mediated signaling. Journal of Virology $\mathbf{8 2}$ 11066-11072. (doi:10.1128/JVI.01300-08)

Kemp CJ \& Drinkwater NR 1989 Genetic variation in liver tumor susceptibility, plasma testosterone levels, and androgen receptor binding in six inbred strains of mice. Cancer Research 49 5044-5047.

Kew MC, Kirschner MA, Abrahams GE \& Katz M 1977 Mechanism of feminization in primary liver cancer. New England Journal of Medicine 296 1084-1088. (doi:10.1056/NEJM197705122961903)

Kley HK 1979 Plasma-estrogens and liver cirrhosis. Zeitschrift für Gastroenterologie 17 406-412.

Kuper H, Lagiou P, Mucci LA, Tamimi R, Benetou V \& Trichopoulos D 2001a Risk factors for cholangiocarcinoma in a low risk Caucasian population. Sozial- und Praventivmedizin 46 182-185. (doi:10.1007/BF01324254)

Kuper H, Mantzoros C, Lagiou P, Tzonou A, Tamimi R, Mucci L, Benetou V, Spanos E, Stuver SO \& Trichopoulos D 2001 $b$ Estrogens, testosterone and sex hormone binding globulin in relation to liver cancer in men. Oncology 60 355-360. (doi:10.1159/000058532)

Kwon H \& Lok AS 2011 Does antiviral therapy prevent hepatocellular carcinoma? Antiviral Therapy 16 787-795. (doi:10.3851/IMP1895)

Lai KP, Yamashita S, Huang CK, Yeh S \& Chang C 2012 Loss of stromal androgen receptor leads to suppressed prostate tumourigenesis via modulation of pro-inflammatory cytokines/chemokines. EMBO Molecular Medicine 4 791-807. (doi:10.1002/emmm.201101140)

Lai KP, Huang CK, Chang YJ, Chung CY, Yamashita S, Li L, Lee SO, Yeh S \& Chang C 2013 New therapeutic approach to suppress castrationresistant prostate cancer using ASC-J9 via targeting androgen receptor in selective prostate cells. American Journal of Pathology 182 460-473. (doi:10.1016/j.ajpath.2012.10.029)
Lampropoulou-Karatzas C, Goritsas P \& Makri MG 1993 Low serum testosterone: a special feature of hepatocellular carcinoma. European Journal of Medicine 2 23-27.

Lee MH, Yang HI, Jen CL, Lu SN, Yeh SH, Liu CJ, You SL, Sun CA, Wang LY, Chen WJ et al. 2011 Community and personal risk factors for hepatitis $C$ virus infection: a survey of 23,820 residents in Taiwan in 1991-2. Gut 60 688-694. (doi:10.1136/gut.2010.220889)

Li Z, Tuteja G, Schug J \& Kaestner KH 2012 Foxa1 and Foxa2 are essential for sexual dimorphism in liver cancer. Cell 148 72-83. (doi:10.1016/j. cell.2011.11.026)

Lim KC, Chow PK, Allen JC, Siddiqui FJ, Chan ES \& Tan SB 2012 Systematic review of outcomes of liver resection for early hepatocellular carcinoma within the Milan criteria. British Journal of Surgery 99 1622-1629. (doi:10.1002/bjs.8915)

Lin HY, Xu Q, Yeh S, Wang RS, Sparks JD \& Chang C 2005 Insulin and leptin resistance with hyperleptinemia in mice lacking androgen receptor. Diabetes 54 1717-1725. (doi:10.2337/diabetes.54.6.1717)

Lin HY, Yu IC, Wang RS, Chen YT, Liu NC, Altuwaijri S, Hsu CL, Ma WL, Jokinen J, Sparks JD et al. 2008 Increased hepatic steatosis and insulin resistance in mice lacking hepatic androgen receptor. Hepatology 47 1924-1935. (doi:10.1002/hep.22252)

Liossi AK, Aroni KG, Kyrkou KA, Kittas C \& Markaki SP 1988 Immunohistochemical study of sex steroid hormones in primary liver cancer. Cancer Detection and Prevention 13 195-201.

Littmann KP, Winter G \& Gerdes H 1973 Gerdes Aktivitätsänderungen testosteroninaktivierender Enzyme in menschlichem Lebergewebe bei Cholostase und Lebercirrhose. Verhandlungen der Deutschen Gesellschaft für Innere Medizin 79 1258-1261.

Llovet JM, Ricci S, Mazzaferro V, Hilgard P, Gane E, Blanc JF, de Oliveira AC, Santoro A, Raoul JL, Forner A et al. 2008 Sorafenib in advanced hepatocellular carcinoma. New England Journal of Medicine 359 378-390. (doi:10.1056/NEJMoa0708857)

Lund J, Zaphiropoulos PG, Mode A, Warner M \& Gustafsson JA 1991 Hormonal regulation of cytochrome P-450 gene expression. Advances in Pharmacology 22 325-354.

Ma WL, Hsu CL, Wu MH, Wu CT, Wu CC, Lai JJ, Jou YS, Chen CW, Yeh S \& Chang C 2008 Androgen receptor is a new potential therapeutic target for the treatment of hepatocellular carcinoma. Gastroenterology 135 947-955. 955 e941-945. (doi:10.1053/j.gastro.2008.05.046)

Ma W, Jeng L, Yeh C \& Chang C 2012a Androgen and androgen receptor signals jamming monocyte/macrophage functions in premalignant phase of livers. Biomedicine 2 155-159. (doi:10.1016/j.biomed. 2012.09.001)

Ma WL, Hsu CL, Yeh CC, Wu MH, Huang CK, Jeng LB, Hung YC, Lin TY, Yeh S \& Chang C 2012b Hepatic androgen receptor suppresses hepatocellular carcinoma metastasis through modulation of cell migration and anoikis. Hepatology 56 176-185. (doi:10.1002/hep.25644)

Magyar Z, Bekesi G, Racz K, Feher J, Schaff Z, Lengyel G, Blazovics A, Illyes G, Szombath D, Hrabak A et al. 2011 Increased total scavenger capacity and decreased liver fat content in rats fed dehydroepiandrosterone and its sulphate on a high-fat diet. Gerontology 57 343-349. (doi:10.1159/ 000321385)

Maheshwari A \& Thuluvath PJ 2011 Endocrine diseases and the liver. Clinics in Liver Disease 15 55-67. (doi:10.1016/j.cld.2010.09.008)

Mancino A, Mancino MG, Glaser SS, Alpini G, Bolognese A, Izzo L, Francis H, Onori P, Franchitto A, Ginanni-Corradini S et al. 2009 Estrogens stimulate the proliferation of human cholangiocarcinoma by inducing the expression and secretion of vascular endothelial growth factor. Digestive and Liver Disease 41 156-163. (doi:10.1016/j.dld.2008.02.015)

Manso G, Thole Z, Salgueiro E, Revuelta P \& Hidalgo A 2006 Spontaneous reporting of hepatotoxicity associated with antiandrogens: data from the Spanish pharmacovigilance system. Pharmacoepidemiology and Drug Safety 15 253-259. (doi:10.1002/pds.1168)

Marsh Rde W, Alonzo M, Bajaj S, Baker M, Elton E, Farrell TA, Gore RM, Hall C, Nowak J, Roy H et al. 2012a Comprehensive review of the diagnosis and treatment of biliary tract cancer 2012. Part I: 
diagnosis-clinical staging and pathology. Journal of Surgical Oncology 106 332-338. (doi:10.1002/jso.23028)

Marsh Rde W, Alonzo M, Bajaj S, Baker M, Elton E, Farrell TA, Gore RM, Hall C, Nowak J, Roy H et al. 2012b Comprehensive review of the diagnosis and treatment of biliary tract cancer 2012. Part II: multidisciplinary management. Journal of Surgical Oncology $\mathbf{1 0 6}$ 339-345. (doi:10.1002/jso.23027)

Matsuzaki Y, Nagai D, Ichimura E, Goda R, Tomura A, Doi M \& Nishikawa K 2006 Metabolism and hepatic toxicity of flutamide in cytochrome P450 1A2 knockout SV129 mice. Journal of Gastroenterology 41 231-239. (doi:10.1007/s00535-005-1749-y)

Michalopoulos GK \& DeFrances MC 1997 Liver regeneration. Science 276 60-66. (doi:10.1126/science.276.5309.60)

Miyamoto H, Yang Z, Chen YT, Ishiguro H, Uemura H, Kubota Y, Nagashima Y, Chang YJ, Hu YC, Tsai MY et al. 2007 Promotion of bladder cancer development and progression by androgen receptor signals. Journal of the National Cancer Institute 99 558-568. (doi:10.1093/ jnci/djk113)

Mode A, Tollet P, Strom A, Legraverend C, Liddle C \& Gustafsson JA 1992 Growth hormone regulation of hepatic cytochrome $\mathrm{P} 450$ expression in the rat. Advances in Enzyme Regulation 32 255-263. (doi:10.1016/00652571(92)90021-Q)

Motomura T, Shirabe K, Mano Y, Muto J, Toshima T, Umemoto Y, Fukuhara T, Uchiyama H, Ikegami T, Yoshizumi T et al. 2013 Neutrophil-lymphocyte ratio reflects hepatocellular carcinoma recurrence after liver transplantation via inflammatory microenvironment. Journal of Hepatology 58 58-64. (doi:10.1016/j.jhep.2012.08.017)

Murakami Y, Fukasawa M, Kaneko Y, Suzuki T, Wakita T \& Fukazawa H 2013 Selective estrogen receptor modulators inhibit hepatitis $\mathrm{C}$ virus infection at multiple steps of the virus life cycle. Microbes and Infection 15 45-55. (doi:10.1016/j.micinf.2012.10.003)

Murray M, Cantrill E, Mehta I \& Farrell GC 1992 Impaired expression of microsomal cytochrome P450 2C11 in choline-deficient rat liver during the development of cirrhosis. Journal of Pharmacological and Experimental Therapeutics 261 373-380.

Nagasue N, Yu L, Yukaya H, Kohno H \& Nakamura T 1995 Androgen and oestrogen receptors in hepatocellular carcinoma and surrounding liver parenchyma: impact on intrahepatic recurrence after hepatic resection. British Journal of Surgery 82 542-547. (doi:10.1002/bjs.1800820435)

Nakatani T, Roy G, Fujimoto N, Asahara T \& Ito A 2001 Sex hormone dependency of diethylnitrosamine-induced liver tumors in mice and chemoprevention by leuprorelin. Japanese Journal of Cancer Research 92 249-256. (doi:10.1111/j.1349-7006.2001.tb01089.x)

Naugler WE, Sakurai T, Kim S, Maeda S, Kim K, Elsharkawy AM \& Karin M 2007 Gender disparity in liver cancer due to sex differences in MyD88-dependent IL-6 production. Science 317 121-124. (doi:10.1126/ science.1140485

Nieschlag E, Cuppers HJ \& Wickings EJ 1977 Influence of sex, testicular development and liver function on the bioavailability of oral testosterone. European Journal of Clinical Investigation 7 145-147. (doi:10.1111/j.1365-2362.1977.tb01588.x)

Oshima H 1968 Androgens. Horumon to Rinsho 16 863-872.

Peng CY, Chien RN \& Liaw YF 2012 Hepatitis B virus-related decompensated liver cirrhosis: benefits of antiviral therapy. Journal of Hepatology 57 442-450. (doi:10.1016/j.jhep.2012.02.033)

Rambaldi A \& Gluud C 2006 Anabolic-androgenic steroids for alcoholic liver disease. Cochrane Database of Systematic Reviews CD003045.

Rinaldi C, Lesmana A \& LA Lesmana 2011 The role of liver biopsy in the non-invasive methods era and liver stiffness measurement using transient elastography. In Liver Biopsy, ch 1. Ed H Takahashi. Rijeka, Croatia: InTech. (doi:10.5772/19561)

Rogers AB, Theve EJ, Feng Y, Fry RC, Taghizadeh K, Clapp KM, Boussahmain C, Cormier KS \& Fox JG 2007 Hepatocellular carcinoma associated with liver-gender disruption in male mice. Cancer Research 67 11536-11546. (doi:10.1158/0008-5472.CAN-07-1479)
Rossi L, Leveri M, Gritti C, De Silvestri A, Zavaglia C, Sonzogni L, Silvestri L, Civardi E, Mondelli MU \& Silini EM 2003 Genetic polymorphisms of steroid hormone metabolizing enzymes and risk of liver cancer in hepatitis C-infected patients. Journal of Hepatology 39 564-570. (doi:10.1016/S0168-8278(03)00355-6)

Ruggieri A, Barbati C \& Malorni W 2010 Cellular and molecular mechanisms involved in hepatocellular carcinoma gender disparity. International Journal of Cancer 127 499-504. (doi:10.1002/ijc.25298)

Saint-Aubert B, Vic P, Brissac C, Bories P, Humeau C, Joyeux H \& Solassol C 1980 Hepatic regeneration in the rat after subtotal (90\%) hepatectomy treated with testosterone. Comptes rendus de l'Académie des Sciences D. Sciences Naturelles 291 653-655.

Samaras V, Rafailidis PI, Mourtzoukou EG, Peppas G \& Falagas ME 2010 Chronic bacterial and parasitic infections and cancer: a review. Journal of Infection in Developing Countries 4 267-281.

Sato K \& Mori M 2011 Evolving molecular mechanism-based strategies for control of hepatocellular carcinoma. Current Medicinal Chemistry 18 4375-4388. (doi:10.2174/092986711797200462)

Schiff ER, Sorrell MF \& Maddrey WC 2003 Schiff's Disease of the Liver. Philadelphia, PA: Lippincott William \& Wilkins.

Schwingel PA, Cotrim HP, Salles BR, Almeida CE, dos Santos CR Jr, Nachef B, Andrade AR \& Zoppi CC 2011 a Anabolic-androgenic steroids: a possible new risk factor of toxicant-associated fatty liver disease. Liver International 31 348-353. (doi:10.1111/j.1478-3231.2010.02346.x)

Schwingel PA, Zoppi CC \& Cotrim HP $2011 b$ Increased liver steatosis in anabolic-androgenic steroid users: more evidence towards toxicantassociated fatty liver disease development. Liver International 31 1240-1241. (doi:10.1111/j.1478-3231.2011.02552.x)

Seki S, Habu Y, Kawamura T, Takeda K, Dobashi H, Ohkawa T \& Hiraide H 2000 The liver as a crucial organ in the first line of host defense: the roles of Kupffer cells, natural killer (NK) cells and NK1.1 Ag + T cells in T helper 1 immune responses. Immunological Reviews 174 35-46. (doi:10.1034/j.1600-0528.2002.017404.x)

Seruga B \& Tannock IF 2011 Chemotherapy-based treatment for castrationresistant prostate cancer. Journal of Clinical Oncology 29 3686-3694. (doi:10.1200/JCO.2010.34.3996)

Sherwood DR, Butler JA, Kramer JM \& Sternberg PW 2005 FOS-1 promotes basement-membrane removal during anchor-cell invasion in C. elegans. Cell 121 951-962. (doi:10.1016/j.cell.2005.03.031)

Shimizu Y 2012 T cell immunopathogenesis and immunotherapeutic strategies for chronic hepatitis B virus infection. World Journal of Gastroenterology 18 2443-2451. (doi:10.3748/wjg.v18.i20.2443)

Shin HS, Kim SU, Park JY, Kim do Y, Han KH, Chon CY, Baatarkhuu O \& Ahn SH 2012 Antiviral efficacy of lamivudine versus entecavir in patients with hepatitis B virus-related advanced hepatocellular carcinoma. Journal of Gastroenterology and Hepatology 27 1528-1534. (doi:10.1111/j.1440-1746.2012.07145.x)

Shirabe K, Mano Y, Muto J, Matono R, Motomura T, Toshima T, Takeishi K, Uchiyama H, Yoshizumi T, Taketomi A et al. 2012 Role of tumor-associated macrophages in the progression of hepatocellular carcinoma. Surgery Today 42 1-7. (doi:10.1007/s00595-011-0058-8)

Sorensen HT, Thulstrup AM, Mellemkjar L, Jepsen P, Christensen E, Olsen JH \& Vilstrup H 2003 Long-term survival and cause-specific mortality in patients with cirrhosis of the liver: a nationwide cohort study in Denmark. Journal of Clinical Epidemiology 56 88-93. (doi:10.1016/S0895-4356(02)00531-0)

Sparks JD \& Sparks CE 2008 Overindulgence and metabolic syndrome: is FoxO1 a missing link? Journal of Clinical Investigation 118 2012-2015.

Swift LL, Farkas MH, Major AS, Valyi-Nagy K, Linton MF \& Fazio S 2001 A recycling pathway for resecretion of internalized apolipoprotein $\mathrm{E}$ in liver cells. Journal of Biological Chemistry 276 22965-22970. (doi:10.1074/jbc.M100172200)

Takahashi Y, Soejima Y \& Fukusato T 2012 Animal models of nonalcoholic fatty liver disease/nonalcoholic steatohepatitis. World Journal of Gastroenterology 18 2300-2308. (doi:10.3748/wjg.v18.i19.2300) http://erc.endocrinology-journals.org DOI: 10.1530/ERC-13-0283
(C) 2014 Society for Endocrinology Printed in Great Britain 
Takami T, Terai S \& Sakaida I 2012 Advanced therapies using autologous bone marrow cells for chronic liver disease. Discovery Medicine 14 7-12. Tamori A \& Kawada N 2012 Interferon. Nippon Rinsho 70 620-624. Tanaka K, Sakai H, Hashizume M \& Hirohata T 2000 Serum testosterone:estradiol ratio and the development of hepatocellular carcinoma among male cirrhotic patients. Cancer Research $605106-5110$.

Tavian D, De Petro G, Pitozzi A, Portolani N, Giulini SM \& Barlati S 2002 Androgen receptor mRNA under-expression in poorly differentiated human hepatocellular carcinoma. Histology and Histopathology 17 1113-1119.

Tejura S, Rodgers GR, Dunion MH, Parsons MA, Underwood JC \& Ingleton PM 1989 Sex-steroid receptors in the diethylnitrosamine model of hepatocarcinogenesis: modifications by gonadal ablation and steroid replacement therapy. Journal of Molecular Endocrinology 3 229-237. (doi:10.1677/jme.0.0030229)

Theve EJ, Feng Y, Taghizadeh K, Cormier KS, Bell DR, Fox JG \& Rogers AB 2008 Sex hormone influence on hepatitis in young male A/JCr mice infected with Helicobacter hepaticus. Infection and Immunity $\mathbf{7 6}$ 4071-4078. (doi:10.1128/IAI.00401-08)

Thole Z, Manso G, Salgueiro E, Revuelta P \& Hidalgo A 2004 Hepatotoxicity induced by antiandrogens: a review of the literature. Urologia Internationalis 73 289-295. (doi:10.1159/000081585)

Tian Y, Kuo CF, Chen WL \& Ou JH 2012 Enhancement of hepatitis B virus replication by androgen and its receptor in mice. Journal of Virology $\mathbf{8 6}$ 1904-1910. (doi:10.1128/JVI.06707-11)

Valero V III, Cosgrove D, Herman JM \& Pawlik TM 2012 Management of perihilar cholangiocarcinoma in the era of multimodal therapy. Expert Review of Gastroenterology \& Hepatology 6 481-495. (doi:10.1586/ egh.12.20)

Vanneaux V, Farge-Bancel D, Lecourt S, Baraut J, Cras A, Jean-Louis F, Brun C, Verrecchia F, Larghero J \& Michel L 2013 Expression of transforming growth factor $\beta$ receptor II in mesenchymal stem cells from systemic sclerosis patients. BMJ Open 3. (doi:10.1136/bmjopen2012-001890)

Vassilatou E, Lafoyianni S, Vryonidou A, Ioannidis D, Kosma L, Katsoulis K, Papavassiliou E \& Tzavara I 2010 Increased androgen bioavailability is associated with non-alcoholic fatty liver disease in women with polycystic ovary syndrome. Human Reproduction 25 212-220. (doi:10.1093/humrep/dep380)

Vizoso FJ, Rodriguez M, Altadill A, Gonzalez-Dieguez ML, Linares A, Gonzalez LO, Junquera S, Fresno-Forcelledo F, Corte MD \& Rodrigo L 2007 Liver expression of steroid hormones and Apolipoprotein D receptors in hepatocellular carcinoma. World Journal of Gastroenterology 13 3221-3227.

Wang AG, Lee KY, Kim SY, Choi JY, Lee KH, Kim WH, Wang HJ, Kim JM, Park MG, Yeom YI et al. 2006 The expression of estrogen receptors in hepatocellular carcinoma in Korean patients. Yonsei Medical Journal 47 811-816. (doi:10.3349/ymj.2006.47.6.811)

Wang J, Su B, Ding Z, Du X \& Wang B 2008 Cimetidine enhances immune response of $\mathrm{HBV}$ DNA vaccination via impairment of the regulatory function of regulatory T cells. Biochemical and Biophysical Research Communications 372 491-496. (doi:10.1016/j.bbrc.2008.04.191)

Wang SH, Yeh SH, Lin WH, Wang HY, Chen DS \& Chen PJ 2009 Identification of androgen response elements in the enhancer I of hepatitis B virus: a mechanism for sex disparity in chronic hepatitis B. Hepatology 50 1392-1402. (doi:10.1002/hep.23163)

Waxman DJ \& O'Connor C 2006 Growth hormone regulation of sex-dependent liver gene expression. Molecular Endocrinology 20 2613-2629. (doi:10.1210/me.2006-0007)

Weickert MO, Hodges P, Tan BK \& Randeva HS 2012 Neuroendocrine and endocrine dysfunction in the hyperinsulinemic PCOS patient: the role of metformin. Minerva Endocrinologica 37 25-40.

Weston SR, Leyden W, Murphy R, Bass NM, Bell BP, Manos MM \& Terrault NA 2005 Racial and ethnic distribution of nonalcoholic fatty liver in persons with newly diagnosed chronic liver disease. Hepatology 41 372-379. (doi:10.1002/hep.20554)
White DL, Kanwal F \& El-Serag HB 2012a Association between nonalcoholic fatty liver disease and risk for hepatocellular cancer, based on systematic review. Clinical Gastroenterology and Hepatology 10 1342-1359.e1342. (doi:10.1016/j.cgh.2012.10.001)

White DL, Tavakoli-Tabasi S, Kuzniarek J, Pascua R, Ramsey DJ \& El-Serag HB $2012 b$ Higher serum testosterone is associated with increased risk of advanced hepatitis C-related liver disease in males. Hepatology $\mathbf{5 5}$ 759-768. (doi:10.1002/hep.24618)

Wild S, Roglic G, Green A, Sicree R \& King H 2004 Global prevalence of diabetes: estimates for the year 2000 and projections for 2030. Diabetes Care 27 1047-1053. (doi:10.2337/diacare.27.5.1047)

Williams R 2006 Global challenges in liver disease. Hepatology 44 521-526. (doi:10.1002/hep.21347)

Wright TL \& Lau JY 1993 Clinical aspects of hepatitis B virus infection. Lancet 342 1340-1344. (doi:10.1016/0140-6736(93)92250-W)

Wu MH, Ma WL, Hsu CL, Chen YL, Ou JH, Ryan CK, Hung YC, Yeh S \& Chang C 2010 Androgen receptor promotes hepatitis B virus-induced hepatocarcinogenesis through modulation of hepatitis B virus RNA transcription. Science Translational Medicine 2 32ra35.

Yang Z, Chang YJ, Yu IC, Yeh S, Wu CC, Miyamoto H, Merry DE, Sobue G, Chen LM, Chang SS et al. 2007 ASC-J9 ameliorates spinal and bulbar muscular atrophy phenotype via degradation of androgen receptor. Nature Medicine 13 348-353. (doi:10.1038/nm1547)

Yang X, Zhang YK, Esterly N, Klaassen CD \& Wan YJ 2009 Gender disparity of hepatic lipid homoeostasis regulated by the circadian clock. Journal of Biochemistry 145 609-623. (doi:10.1093/jb/mvp018)

Yang F, Yin Y, Wang F, Zhang L, Wang Y \& Sun S 2010 An altered pattern of liver apolipoprotein A-I isoforms is implicated in male chronic hepatitis B progression. Journal of Proteome Research 9 134-143. (doi:10.1021/ pr900593r)

Yau T, Chan P, Epstein R \& Poon RT 2009 Management of advanced hepatocellular carcinoma in the era of targeted therapy. Liver International 29 10-17. (doi:10.1111/j.1478-3231.2008.01916.x)

Yeh SH \& Chen PJ 2010 Gender disparity of hepatocellular carcinoma: the roles of sex hormones. Oncology 78 (Suppl 1) 172-179. (doi:10.1159/ 000315247)

Yeh S, Chang HC, Miyamoto H, Takatera H, Rahman M, Kang HY, Thin TH, Lin HK \& Chang C 1999 Differential induction of the androgen receptor transcriptional activity by selective androgen receptor coactivators. Keio Journal of Medicine 48 87-92. (doi:10.2302/kjm.48.87)

Yoon G, Kim JY, Choi YK, Won YS \& Lim IK 2006 Direct activation of TGF-beta1 transcription by androgen and androgen receptor complex in Huh7 human hepatoma cells and its tumor in nude mice. Journal of Cellular Biochemistry 97 393-411. (doi:10.1002/ jcb.20638)

Yoshitsugu M \& Ihori M 1997 Endocrine disturbances in liver cirrhosisfocused on sex hormones. Nippon Rinsho 55 3002-3006.

Yu L, Kubota H, Imai K, Yamaguchi M \& Nagasue N 1997 Heterogeneity in androgen receptor levels and growth response to dihydrotestosterone in sublines derived from human hepatocellular carcinoma line (KYN-1). Liver 17 35-40. (doi:10.1111/j.1600-0676.1997.tb00776.x)

Yu MW, Cheng SW, Lin MW, Yang SY, Liaw YF, Chang HC, Hsiao TJ, Lin SM, Lee SD \& Chen PJ 2000 Androgen-receptor gene CAG repeats, plasma testosterone levels, and risk of hepatitis B-related hepatocellular carcinoma. Journal of the National Cancer Institute 92 2023-2028. (doi:10.1093/jnci/92.24.2023)

Yu MW, Yang YC, Yang SY, Cheng SW, Liaw YF, Lin SM \& Chen CJ 2001 Hormonal markers and hepatitis B virus-related hepatocellular carcinoma risk: a nested case-control study among men. Journal of National Cancer Institute 93 1644-1651. (doi:10.1093/jnci/93.21.1644)

Yuan JM, Ross RK, Stanczyk FZ, Govindarajan S, Gao YT, Henderson BE \& Yu MC 1995 A cohort study of serum testosterone and hepatocellular carcinoma in Shanghai, China. International Journal of Cancer 63 491-493. (doi:10.1002/ijc.2910630405)

Yurci A, Yucesoy M, Unluhizarci K, Torun E, Gursoy S, Baskol M, Guven K \& Ozbakir O 2011 Effects of testosterone gel treatment in 
hypogonadal men with liver cirrhosis. Clinics and Research in Hepatology and Gastroenterology 35 845-854. (doi:10.1016/j.clinre. 2011.09.005)

Zhang Y, Chen WL, Ma WL, Chang C \& Ou JH 2007 Enhancement of gene transactivation activity of androgen receptor by hepatitis $\mathrm{B}$ virus X protein. Virology 363 454-461. (doi:10.1016/j.virol.2007. 01.040)

Zhang H, Liu Y, Wang L, Li Z, Wu J, Rahman N, Guo Y, Li D, Li N, Huhtaniemi I et al. 2013 Differential effects of estrogen/androgen on the prevention of nonalcoholic fatty liver disease in the male rat. Journal of Lipid Research 54 345-357. (doi:10.1194/jlr.M028969)

Zheng Y, Chen WL, Ma WL, Chang C \& Ou JH 2007 Enhancement of gene transactivation activity of androgen receptor by hepatitis B virus X protein. Virology 363 454-461. (doi:10.1016/j.virol.2007.01.040)

Zhu R, Zhang JS, Zhu YZ, Fan J, Mao Y, Chen Q \& Zhu HG 2011 $\mathrm{HBx}$-induced androgen receptor expression in $\mathrm{HBV}$-associated hepatocarcinoma is independent of the methylation status of its promoter. Histology and Histopathology 26 23-35.

Received in final form 11 December 2013

Accepted 9 January 2014

Made available online as an Accepted Preprint

14 January 2014
Published by Bioscientifica Ltd. 